\title{
Electron Flow through Metalloproteins
}

\author{
Jay R. Winkler ${ }^{*}$ and Harry B. Gray ${ }^{*}$ \\ Beckman Institute, California Institute of Technology, 1200 E. California Boulevard, Pasadena, \\ CA 91125
}

\section{Introduction}

Electron flow through proteins and protein assemblies in the photosynthetic and respiratory machinery commonly occurs between metal centers or other redox cofactors that are separated by relatively large molecular distances, often in the 10 to 20 angstrom range. To inorganic chemists, such long distance electron transfer was a mystery for many years, as we were accustomed to close contact models for the transition states of simple self-exchange reactions between metal ions in aqueous solution. One of our favorite reactions was the ferrous/ferric self-exchange, which had been investigated thoroughly by Richard (Dick) Dodson at the Brookhaven National Laboratory in the 1940s (and published in JACS in 1950). ${ }^{1}$ Dodson showed that the half time for this reaction was on the order of seconds, which he noted was "fast" but in today's femtosecond world is very "slow". Indeed, this very simple electron transfer, where no bonds are formed or broken, was found to be orders of magnitude slower than long distance electron flow through metalloprotein molecules. How could this be?

The investigations of electron exchange kinetics ${ }^{2-9}$ motivated theorists to try to account for the diversity of reaction rates found for these processes. In 1952, Willard Libby, citing insights from James Franck, argued that the Franck-Condon principle played a critical role in electron transfer. ${ }^{10} \mathrm{He}$ envisioned a process in which an electron jumped from one ion to the next while the nuclei remained fixed. This transition would produce ions in incorrect solvation environments; rearrangement of slower-moving nuclei subsequent to the electron hop created the barrier to reaction. Libby estimated that the activation enthalpy corresponded to the difference in hydration enthalpies of the reacting ions.

Two years later, Rudolph J. Marcus, Bruno J. Zwolinski, and Henry Eyring (MZE) offered a revised interpretation of the role of the Franck-Condon principle in electron exchange reactions. ${ }^{11}$ They recognized that the processes envisioned by Libby did not conserve energy. Instead, MZE argued that as hydrated ions approach the transition state for electron exchange, the hydration shells of both ions must rearrange until, at the transition state, they are symmetrical. While the ions are in this symmetric configuration an electron can rapidly hop from the reduced ion to the oxidized partner leaving the total energy unchanged. The barrier to the electron exchange arises from the energy required to reorganize the hydration spheres on the two ions to reach the degenerate configuration. A subsequent review by the same three authors (ZME) rationalized the wide span of observed electron exchange rate constants. ${ }^{12}$ They concluded that the height of the electron exchange barrier was governed by the similarity of the structures of the reactants. ZME were not able to make predictions of exchange rate constants because they lacked a quantitative model for the nuclear reorganization energy.

*Corresponding Author: winklerj@caltech.edu; hbgray@caltch.edu. 
It took another Rudolph Marcus (Rudolph A., RAM) to put all of the pieces together, which he did by developing an analytical theory for electron-transfer reactions. ${ }^{13}$ Marcus adopted a nuclear-reorganization first, electron-hop second model, attributing the bulk of the reorganization to polarization of a continuous dielectric medium surrounding the ions. Using a model for the electrostatic free energies of states having nonequilibrium polarization, RAM developed an expression for the activation free energy for electron transfer in terms of solvent dielectric properties, ionic charges and radii of reactants and products, and the standard free-energy of reaction. Later refinements to the model introduced contributions to the barrier from reorganization of the inner coordination spheres of the ions. The beauty of the RAM formulation was the wide array of reactions to which it could be applied and the direct prediction of specific rates in terms of readily accessible experimental quantities.

Although much effort was expended in describing the nuclear reorganization barrier to electron transfer, virtually every theorist recognized that an electron-tunneling barrier also was likely to oppose the reaction. In all cases, rates were predicted to decay exponentially with increasing separation between the reacting ions. Libby estimated an exponential decay factor of $1.65 \AA^{-1}$ for exchange between $\mathrm{H}$ and $\mathrm{H}^{+}$; a value of $1.21 \AA^{-1}$ emerges from his calculation of the overlap between $3 \mathrm{dz}^{2}$ orbitals in ions of $3+$ charge. ${ }^{10}$ MZE estimated a distance decay factor of $1.23 \AA^{-1}$ for the ferrous/ferric self-exchange reaction on the basis of an electrostatic potential barrier to tunneling. ${ }^{11}$ Marcus adopted this value in a brief discussion of tunneling in his 1956 paper. $^{13}$

In the 1970s, one of us (HBG) met many times with John Hopfield, then at Princeton, with the main topic being the mechanism of electron flow through proteins. During these meetings, we had several intense discussions of the proposal by DeVault and Chance that the reaction involved quantum mechanical tunneling. Hopfield was attempting to reconcile our experimental work on the kinetics of cytochrome $c$ reactions with inorganic redox agents with the temperature dependence of oxidation rates of the protein in photosynthetic reaction centers (PRCs). Then, in a 1974 PNAS paper, Hopfield showed that thermally activated electron tunneling could account quantitatively for the DeVault-Chance PRC-cyt c redox reactions. ${ }^{14}$

Hopfield bypassed the problem of bimolecular electron transfer reactions in which the relative positions of the redox partners are unknown and chose to consider only fixed-site electron transfer. From an experimental perspective, it became clear that a new approach was required: the diffusive encounter of donor and acceptor had to be eliminated in order to reveal the intrinsic barriers to electron transfer. Toward this end, one of us (HBG) initiated a research effort to produce metalloproteins with redox active molecules covalently attached to unique surface sites. After much effort, we managed to obtain $\mathrm{Ru}\left(\mathrm{NH}_{3}\right)_{5}(\mathrm{His} 33)-\mathrm{Fe}-$ cytochrome $c$, and in early 1982 our observation of rapid 18 - $\AA$ electron transfer from $\mathrm{Ru}$ (II) to $\mathrm{Fe}(\mathrm{III})$ in this protein demonstrated that long-range electron tunneling is a viable mechanism for biological electron flow. ${ }^{15}$ Following this discovery, there was an explosion of research on electron tunneling kinetics in model systems and in proteins. ${ }^{16-36}$ It is now clear that electrons tunnel between sites in biological redox chains, and that protein structures tune thermodynamic properties and electronic coupling interactions to facilitate these reactions.

Our review deals with work done on long-range electron transfer over the last 60 years, with a primary focus on results from the Gray laboratory at Caltech. We place particular emphasis on the connections that have been made between theory and experiment that in turn have shed light on the factors that control electron tunneling through proteins and other complex molecular assemblies. A key finding is that macromolecular structures tune 
thermodynamic properties and electronic coupling interactions to facilitate electron flow through biological redox chains.

\section{Reorganization Energy}

The RAM model of electron transfer predicts that the activation free energy $\left(\Delta G^{*}\right)$ will depend on: the work required to bring reactants $\left(w^{r}\right)$ or products $\left(w^{p}\right)$ to the mean separation distance for reaction $(\sigma)$; a reorganization parameter $(\lambda)$; and a work-corrected free energy of reaction $\left(\Delta G^{\circ \prime}=\Delta G^{\circ}+w^{p}-w^{r}\right)($ Eq. 1$){ }^{37}$

$$
\Delta G *=\mathrm{W}^{r}+\frac{\left(G^{\circ \prime}+\lambda\right)^{2}}{4 \lambda}
$$

The reorganization parameter contains contributions from changes in the inner-sphere structures of reactants $\left(\lambda_{i}\right)$ in addition to changes in solvent orientation $\left(\lambda_{o}\right)$. Marcus developed a dielectric continuum model for $\lambda_{\mathrm{o}}$ (Eq. 2)

$$
\lambda_{o}=(\Delta e)^{2}\left[\frac{1}{2 a_{1}}+\frac{1}{2 a_{2}}-\frac{1}{\sigma}\right]\left[\frac{1}{D_{o p}}-\frac{1}{D_{s}}\right]
$$

where $\Delta e$ is the charge transferred, $a_{1}$ and $a_{2}$ are the radii of the two (spherical) reactants, $D_{o p}$ is the solvent optical dielectric constant (taken as the square of the refractive index), and $D_{s}$ is the solvent static dielectric constant. Importantly, larger reactants and lower dielectric media can reduce outer-sphere barriers to electron transfer. Notably, Sutin's analysis of the ferrous/ferric self-exchange suggested that $\lambda_{i}=1.3 \mathrm{eV}$ and $\lambda_{o}=0.9-1.2 \mathrm{eV} .{ }^{38}$ According to this analysis, the total reorganization energy (more than $2.2 \mathrm{eV}$ ) would create a barrier to the exchange reaction in line with the measured rate constant of $4.2 \mathrm{M}^{-1} \mathrm{~s}^{-1}$. Through consideration of inner-sphere structural changes, Brunschwig and coworkers were able to explain quantitatively exchange rate constants varying over fifteen orders of magnitude for twelve different redox partners. ${ }^{39}$

The distinction between inner- and outer-sphere reorganization is blurred somewhat for redox cofactors embedded in polypeptide matrices. Metal redox centers typically are ligated by prosthetic groups (e.g., porphyrins), atoms or small molecules (e.g., $\mathrm{O}^{2-}, \mathrm{S}^{2-}, \mathrm{HO}^{-}$, $\mathrm{H}_{2} \mathrm{O}$ ), amino acid side chains, or even the a-amino group of a polypeptide $\mathrm{N}$-terminus. Constraints imposed by the rigidity of the polypeptide backbone can reduce $\lambda_{i}$ by limiting structural changes at redox centers. ${ }^{40}$ Moreover, partial or complete burial of redox sites within a polar but only moderately polarizable polypeptide ${ }^{41}$ that is embedded in a highdielectric solvent, or in a low-dielectric lipid membrane, will lower $\lambda_{o}$. The reduction in selfexchange reorganization energy $\left(\Delta \lambda_{f}\right)$ that accompanies folding of a polypeptide around a redox cofactor can be expressed (Eq. 3 ) in terms of the difference

$$
\Delta \lambda_{f}=8\left(\Delta G_{f, \ddagger}-\left\langle\Delta G_{f}\right\rangle\right)
$$

between the free energy of folding the polypeptide around the transition state configuration $\left(\Delta G_{f, \ddagger}\right)$ and the average folding free-energy change for the oxidized and reduced proteins $\left(\left\langle\Delta G_{f}\right\rangle\right) .{ }^{42}$ As a consequence of the protein fold around the redox center, self-exchange reorganization energies for redox proteins tend to be less than $1 \mathrm{eV}$, whereas values over twice as great are typically found for transition metal aquo ions (Table 1). ${ }^{38,43-48}$ 


\section{Electronic Coupling}

The reduction of reorganization barriers by burial of redox cofactors in protein interiors comes at a price: since redox centers cannot form close contact encounter complexes, electrons must tunnel long distances through the polypeptide matrix. The semiclassical electron-transfer theory expresses rate constants for fixed-distance reactions $\left(k_{E T}\right)$ as the product of four factors: the effective frequency of motion along the reaction coordinate $\left(v_{N}\right)$; an electronic transmission coefficient $\left(\kappa_{E}\right)$; a nuclear tunneling factor $\left(\Gamma_{\mathrm{N}}\right)$; and an exponential function of $\Delta G^{*}$ (Eq. 4). A Landau-Zener formulation is commonly used to

$$
k_{E T}=v_{N} \kappa_{E} \Gamma_{N} \exp \left(-\frac{\Delta G^{*}}{k_{B} T}\right)
$$

describe the dependence of $\kappa_{E}$ on the electronic coupling between reactants and products $\left(H_{A B}\right)$ and $v_{\mathrm{N}}$ (Eq. 5). ${ }^{49}$ In the limit of small electronic coupling and no nuclear tunneling $\left(\Gamma_{\mathrm{N}}=1\right)$, the ET rate constant is given by Eq 6. The limiting value for the maximum ET rate $\left(k_{E T}^{\circ}=\nu_{\mathrm{N}} \kappa_{E}\right)$ depends on the $\nu_{\mathrm{N}}$ (Figure 1), a quantity that typically depends on solvent or polypeptide reorientation dynamics.

$$
\begin{gathered}
\kappa_{E}=\frac{2 P_{0}}{1+P_{0}} \quad(5 \mathrm{a}) \\
P_{0}=1-\exp (-2 \pi \gamma) \quad(5 \mathrm{~b}) \\
2 \pi \gamma=\frac{\left|H_{A B}\right|^{2} \pi / 2}{h v_{N} \sqrt{k_{B} T \lambda}} \quad(5 \mathrm{c}) \\
k_{E T}=\sqrt{\frac{4 \pi^{3}}{h^{2} \lambda k_{B} T}}\left|H_{A B}\right|^{2} \exp \left(-\frac{\Delta G^{*}}{k_{B} T}\right)
\end{gathered}
$$

After our initial demonstration of long-range electron tunneling through Ru-modified cytochrome $c,{ }^{15}$ work in our laboratory focused on the elucidation of distant electronic couplings between redox sites in several Ru-proteins..$^{29,35,50-53}$ In particular, work on $\mathrm{Ru}-$ azurin provided a benchmark for electron tunneling through folded polypeptide structures. ${ }^{35,50-51}$ The azurin copper center, which is situated at one end of an eight-stranded $\beta$-barrel, is ligated by two imidazoles (His46, His117) and a thiolate (Cys112); in addition, there are two weak axial interactions (Met121 thioether sulfur, Gly45 carbonyl oxygen). ${ }^{54-55}$ The protein from $P$. aeruginosa has two additional His residues, one of which (His83) reacts readily with Ru-labeling reagents. A H83Q base mutant was prepared and individual His residues were introduced at five locations on $\beta$-strands extending from Met121 and Cys112 (K122H, T124H, T126H, Q107H, M109H). ${ }^{50-51}$ Electron tunneling distances $(\mathrm{Ru}-\mathrm{Cu})$ in these $\mathrm{Ru}(\mathrm{bpy})_{2}(\mathrm{im})(\mathrm{HisX})^{2+}(\mathrm{X}=83,122,124,126,107,109)$ proteins range from 16 to $26 \AA$ (Figure 2).

Experimental determination of activationless $\mathrm{Cu}(\mathrm{I}) \rightarrow \mathrm{Ru}(\mathrm{III}) \mathrm{ET}\left(-\Delta \mathrm{G}^{\circ}=0.7 \mathrm{eV}\right)$ in the set of Ru-azurins established the distance dependence of electron transfer along $\beta$ strands. ${ }^{35,50-51}$ The driving-force-optimized protein tunneling timetable exhibits a nearly perfect exponential distance dependence, with a decay constant $(\beta)$ of $1.1 \AA^{-1}$, and an 
intercept at close contact $\left(r_{\mathrm{O}}=3 \AA\right.$ ) of $10^{13} \mathrm{~s}^{-1}$ (Figure 3). Moreover, our studies showed that $\mathrm{Cu}(\mathrm{I})$ to $\mathrm{Ru}(\mathrm{III})$ or $\mathrm{Os}(\mathrm{III}) \mathrm{ET}$ rates in labeled azurin crystals are nearly identical with solution values for each donor-acceptor pair. ${ }^{55}$ The azurin distance decay constant is quite similar to that found for superexchange-mediated tunneling across saturated alkane bridges $\left(\beta \approx 1.0 \AA^{-1}\right),{ }^{56-57}$ strongly indicating that a similar coupling mechanism is operative in the polypeptide. Notably, kinetics data obtained by Farver and Pecht in their work on long-range ET from radiolytically generated disulfide radical anion to $\mathrm{Cu}(\mathrm{II})$ in the blue protein also have been interpreted successfully in terms of this coupling model. ${ }^{58}$

The energy gap between donor/acceptor redox levels and those of oxidized or reduced intermediate states is the primary criterion in determining when hole or electron hopping becomes important. ${ }^{59}$ In Ru-azurin, photogenerated Ru(bpy $)_{2}(\mathrm{im})(\mathrm{His})^{3+}\left(\mathrm{E}^{\circ}=1.0 \mathrm{~V}\right.$ vs. $\mathrm{NHE})^{60}$ potentially could oxidize aromatic (Trp or Tyr) residues. ${ }^{35}$ If $\mathrm{Cu}(\mathrm{I})$ is replaced by $\mathrm{Zn}(\mathrm{II})$ in the protein, however, we find that photogenerated holes in the $\mathrm{Ru}(\mathrm{bpy})_{2}$ (im) $(\mathrm{HisX})^{3+}$ probes remain localized on the Ru center, which means that the energy gap between the $\mathrm{Ru}(\mathrm{III})$ hole and oxidized bridge states must be greater than $75 \mathrm{meV}\left(3 k_{\mathrm{B}} \mathrm{T}\right.$ at $295 \mathrm{~K}$ ). Our finding that the rate of $\mathrm{Cu}(\mathrm{I}) \rightarrow \mathrm{Ru}$ (III) ET in the Ru-protein does not decrease upon lowering the temperature to $240 \mathrm{~K}$ (it actually increases slightly at $160 \mathrm{~K}$ )

demonstrates that hopping does not occur in this case, as a reaction with an endergonic step would be highly disfavored at low temperature. Even more compelling was the observation that $\mathrm{Cu}(\mathrm{I}) \rightarrow \mathrm{Ru}(\mathrm{III}) \mathrm{ET}$ rate in a structurally characterized azurin crystal is roughly the same at low temperature $(140 \mathrm{~K})$ as at $298 \mathrm{~K} .{ }^{55}$

The rates of high-driving-force ET reactions have been measured for more than 30 $\mathrm{Ru}$ (diimine)-labeled metalloproteins (Figure 4). ${ }^{29,35,48,52}$ Driving-force-optimized values are scattered around the protein benchmark $1.1 \AA^{-1}$ distance decay. Our finding that D/A distances that differ by as much as $5 \AA$ can produce virtually identical rates shows clearly that protein structure can play a key role in coupling redox centers.

The $10^{13} \mathrm{~s}^{-1}$ intercept at $\mathrm{r}_{\mathrm{o}}=3 \AA$ represents the "ET speed limit"; it is the specific rate expected for ET between two redox centers in the adiabatic coupling limit. Direct comparisons between this extrapolated value and ultrafast ET data are complicated by medium dynamics: as donor-acceptor electronic coupling increases, a regime is reached where rates are no longer limited by the strength of this coupling, but by solvent reorientation dynamics $\left(v_{N}\right)$, as discussed above. This so-called solvent controlled adiabatic limit will typically fall below the rate constant $\left(k_{N A}^{\circ}\right)$ for the nonadiabatic reaction determined by extrapolation of rate-distance data to a close-contact intercept.

Small (D/A) molecules provide estimates of close-contact ET rates. A case in point is work by Barbara and coworkers on thermal ET following metal-to-metal charge transfer (MMCT) excitation in $\left(\mathrm{NH}_{3}\right)_{5} \mathrm{Ru}^{\mathrm{III}} \mathrm{NCM}^{\mathrm{II}}(\mathrm{CN})_{5}{ }^{-}(\mathrm{M}=\mathrm{Fe}, \mathrm{Ru}),{ }^{61-62}$ which are mixed-valence complexes in the Robin-Day Class II category ${ }^{63}$ with MMCT extinction coefficients $\sim 3 \times$ $10^{3} \mathrm{M}^{-1} \mathrm{~cm}^{-1}$ and electronic coupling parameters of about $1900(\mathrm{M}=\mathrm{Ru})$ and $1500 \mathrm{~cm}^{-1}$ $(\mathrm{M}=\mathrm{Fe})^{61}$. In solvents with relatively fast dielectric relaxation (e.g., $\mathrm{H}_{2} \mathrm{O}$, formamide, $\mathrm{N}$ methyl-formamide), the $\mathrm{Ru}^{\mathrm{II}} \rightarrow \mathrm{Fe}^{\mathrm{III}}$ and $\mathrm{Ru}^{\mathrm{II}} \rightarrow \mathrm{Ru}^{\mathrm{III}} \mathrm{ET}$ rate constants were found to be $\sim 10^{13} \mathrm{~s}^{-1}$. Solvent relaxation dynamics typically fall into two distinct timescales: fast components corresponding to inertial motions of the solvent occur in tens of femtoseconds; and slow processes $(>0.5 \mathrm{ps})$ attributable to overdamped motions arising from dielectric friction associated with collective solvent reorientation. ${ }^{64}$ Because ET in $\left(\mathrm{NH}_{3}\right)_{5} \mathrm{Ru}^{\mathrm{III}} \mathrm{NCM}^{\mathrm{II}}(\mathrm{CN})_{5}{ }^{-}$is faster than slow solvent relaxation components, Barbara concluded that overdamped solvent motions play only a minor role in the ultrafast reaction. ${ }^{61-62}$ Hence, in these mixed-valence complexes, specific ET rates are $\sim 10^{13} \mathrm{~s}^{-1}$ at a metal-metal separation of $\sim 5 \AA .^{65}$ 
The electronic coupling in $\left(\mathrm{NH}_{3}\right)_{5} \mathrm{Ru}^{\mathrm{III}} \mathrm{NCM}^{\mathrm{II}}(\mathrm{CN})_{5}-(\mathrm{M}=\mathrm{Fe}, \mathrm{Ru})$ can be compared to that in $\mathrm{Fe}(\mathrm{CN})_{6}{ }^{2-} \mid \mathrm{Ru}\left(\mathrm{NH}_{3}\right)_{6}{ }^{3+}$ complexes. ${ }^{66}$ An intervalence absorption maximum at $730 \mathrm{~nm}$ with an extinction coefficient of $34 \mathrm{M}^{-1} \mathrm{~cm}^{-1}$ is consistent with a coupling of $150 \mathrm{~cm}^{-1}$ at an estimated M-M separation of $\sim 7.6 \AA{ }^{66-68}$ Notably, the 2.5 - $\AA$ increase in M-M distance on going from the $\mathrm{CN}$-bridged complex to the contact ion pair is accompanied by a 10 -fold decrease in electronic coupling.

Photoinitiated ET transitions in charge transfer (CT) complexes allow other comparisons to our extrapolated maximum rate constant. Spears and coworkers examined viologen (methyl viologen, MV; heptyl viologen, HV) complexes with 4,4'-biphenol (BP). ${ }^{69}$ The noncovalent interaction between the two redox groups is similar to that in the contact ion pairs; the CT extinction coefficients are $\sim 4 \times 10^{1} \mathrm{M}^{-1} \mathrm{~cm}^{-1}$ and the estimated couplings are 361 (MV) and $381 \mathrm{~cm}^{-1}(\mathrm{HV})$. Ab initio calculations of the optimum MV-BP ground-state geometry predict a $4 \AA$ A separation between planes of the aromatic rings. The specific ET rates following ultrafast excitation into the $\mathrm{CT}$ absorption band in fast-relaxing solvents (e.g., methanol, acetonitrile) are $\sim 2.5 \times 10^{12} \mathrm{~s}^{-1}$. It is likely that each of these thermal ET reactions falls in the solvent-controlled adiabatic limit; the estimated specific rate in the absence of solvent control is $2.5 \times 10^{13} \mathrm{~s}^{-1} .69$

The foregoing ultrafast ET results are consistent with the $k_{E T}$ value $\left(10^{13} \mathrm{~s}^{-1}\right)$ extrapolated to close contact between redox sites in Ru-proteins. The separation distance at this limit depends on whether the two sites are covalently coupled or are in van der Waals contact. For intraprotein ET between two metal complexes (i.e., $\mathrm{Ru}(\mathrm{bpy})_{2}(\mathrm{im})(\mathrm{HisX})^{3+}$ and $\mathrm{Cu}(\mathrm{His} 46)$ (His117)(Cys112)(Met121) $)^{+}$, we suggest that an ET rate of $10^{13} \mathrm{~s}^{-1}$ will require van der Waals contact between the two metal redox centers.

Empirical data from Ru-modified proteins demonstrate conclusively that long-range electron tunneling rates depend critically on the composition and structure of the medium between two redox centers. The polypeptide matrices of folded proteins are not homogeneous media and consequently the tunneling rates do not exhibit uniform exponential distance dependences. It is convenient to characterize the coupling efficiency of a particular polypeptide matrix by an effective exponential decay constant $\left(\beta^{\prime}\right)$. Taking the data in Figure 4 , we can define $\beta^{\prime}$ values for each Ru-protein, assuming an intercept at close contact $\left(r_{\mathrm{O}}=3\right.$ $\AA$ ) of $10^{13} \mathrm{~s}^{-1}$. The histogram of $\beta^{\prime}$ values (Figure 5) reveals an asymmetric distribution peaking near $1.0 \AA^{-1}$, with extremes of 0.85 and $1.5 \AA^{-1}$. This range of $\beta^{\prime}$ values is entirely consistent with those obtained from investigations of the ET reactions of synthetic donorbridge-acceptor complexes..$^{56-57}$

Heterogeneous polypeptide matrices are not unlike frozen glasses as electron tunneling media. In one experimental study, we found that decay constants for tunneling through aqueous and tetrahydrofuran glasses $\left(1.6 \AA^{-1}\right)$ are substantially greater than those for most proteins (Figure 4). Tunneling across oligoxylene bridges, an all-covalent analogue of glassy toluene $\left(1.2 \AA^{-1}\right)$, is far more efficient $\left(0.75 \AA^{-1}\right)$. It is interesting to note that these tunneling rate constants extrapolated to close contact $\left(0.5-5 \times 10^{13} \mathrm{~s}^{-1}\right)$ are in good agreement with that found for Ru-modified azurin. In terms of long-range coupling efficiency, however, frozen glasses are greatly inferior to polypeptide matrices as ET media; the larger $\beta$ values in solvents are likely a consequence of the predominance of van der Waals contacts over covalent contacts between donors and acceptors. ${ }^{70}$

Since the early 1980s, hundreds of intramolecular ET rates have been reported. ${ }^{71}$ Electronic coupling strengths are not always available from these studies, but in some instances it has been possible through driving-force variations to separate the nuclear and electronic contributions to the observed ET rate constants. ${ }^{35,72-74}$ Moreover, starting with work in the 
1950s, electronic coupling strengths in mixed-valence complexes have been evaluated using the Mulliken-Hush protocol. ${ }^{75-78}$ These results $\left(H_{A B}\right.$ versus donor-acceptor distance $\left.\mathrm{R}\right)$ are compared with those from Ru-modified proteins in Figure $6 .{ }^{35,72-74,76-78} \mathrm{R}$ values for metal complexes are metal-metal distances, whereas those for aromatic organic redox cofactors are to the nearest aromatic carbon atom. It is clear from this plot that an exponential decay with $\beta=1.1 \AA^{-1}$ is a good zero-order approximation to the distance dependence of couplings derived from ET rate measurements. With one exception, ${ }^{73}$ couplings extracted from intervalence charge transfer (IVCT) measurements, however, are substantially greater than expected for their separation distances. Detectable IVCT bands are typically found only for strongly coupled systems (extinctions coefficients $>10 \mathrm{M}^{-1} \mathrm{~cm}^{-1}, H_{A B}>10^{2} \mathrm{~cm}^{-1}$ ) and examples where $H_{A B}$ has been estimated from both spectroscopic and kinetics data are rare. ${ }^{79-80}$ Direct ET rate measurements in these systems could provide insight into the discrepancies highlighted in Figure 6.

\section{Theory}

The ferrous/ferric exchange reaction, particularly the surprisingly large deuterium isotope effect $k_{\mathrm{H}} / k_{\mathrm{D}} \sim 2$ reported by Hudis and Dodson, ${ }^{81}$ was a tempting challenge for the theoretical community. ${ }^{82-87}$ Hudis and Dodson suggested that a hydrogen-atom transfer mechanism was operating. A subsequent analysis by Friedman and Newton, however, suggested that a value of $k_{\mathrm{H}} / k_{\mathrm{D}}=1.7$ was consistent with quantitatively known contributions to the reorganization barrier for a simple outer-sphere electron exchange reaction. ${ }^{88}$ Chandler found that a substantial contribution from nuclear tunneling in the solvent water molecules contributed to the isotope effect. ${ }^{86}$ Molecular modeling produced a reorganization barrier in excellent agreement with experiment and provided strong theoretical support for the RAM model. ${ }^{87}$

Warshel and coworkers took on the challenge of calculating protein reorganization energies. ${ }^{89}$ The observed structural changes between oxidized and reduced cytochrome c formed the basis of a microscopic treatment of the barrier to electron exchange that predicted an order-of-magnitude reduction in $\lambda$ for cytochrome $c$ compared to the $\mathrm{Fe}\left(\mathrm{OH}_{2}\right)_{6}{ }^{3+} / \mathrm{Fe}\left(\mathrm{OH}_{2}\right)_{6}{ }^{2+}$ couple. Ryde and coworkers used DFT calculations to estimate inner-sphere reorganization energies for electron-transfer proteins. ${ }^{90-92}$ Smaller reorganization energies were found for heme and iron-sulfur proteins than for copper proteins, and general principles for $\lambda$ reduction in proteins were identified. ${ }^{92}$

Shortly after the first measurement of intramolecular electron transfer in Ru-modified cytochrome $c$, theoreticians began to address many of the questions raised by the results of these experiments. The first entry into the field was a paper by K. F. Freed rationalizing the small variation of $k_{E T}$ with temperature in terms of the theory of radiationless transitions. ${ }^{18}$

The subject of greatest interest to theoreticians, however, was the electronic coupling between distant redox centers. As noted above, Hopfield already had explained tunneling in photosynthetic reaction centers in terms of a square-barrier model. ${ }^{14}$ This extremely coarsegrained approach was reasonable at the time, given the absence of atomic-level structural information. Efforts to explain long-range ET in terms of square-barrier models persist to this day in spite of the wealth of high-resolution protein structures that are now available and the clear experimental evidence that the electronic coupling between two redox centers depends on the structure and composition of the intervening medium. ${ }^{93}$

An early effort to understand the role of the intervening medium in long-range ET came from Kuki and Wolynes, who used a quantum path integral Monte Carlo method to analyze tunneling pathways in Ru-modified myoglobins. ${ }^{22} \mathrm{~A}$ few years later, Beratan and Onuchic 
developed a generalization of the McConnell superexchange coupling model that was able to account for the scatter in the tunneling timetables of Ru-proteins. ${ }^{94-96}$ In this all-atom tunneling-pathway model, the medium between $\mathbf{D}$ and $\mathbf{A}$ is decomposed into a series of covalent bonds, hydrogen bonds, or through-space jumps. A coupling decay is assigned to each of the three types of contact, and a structure-searching algorithm ranks the coupling efficiencies of the pathways between $\mathbf{D}$ and $\mathbf{A}$. The pathways model was one of the first to explain the heterogeneity of the distance dependence of electron transfer rates in $\mathrm{Ru}$ modified proteins. ${ }^{96-97}$ More elaborate computational protocols also have been developed that shed light on the factors that determine distant couplings in proteins. ${ }^{98-111}$

In the early 1990s, Evenson and Karplus examined the role that tunneling energy likely would play in the distance dependence of long-range ET rates. ${ }^{28}$ Following their work, Stuchebrukhov developed an all-atom coupling model to analyze long-range electron transfer in Ru-modified proteins. ${ }^{12-116}$ The tunneling currents through all of the atoms in a pruned protein ${ }^{117}$ were calculated and used to evaluate the overall D-A coupling. The analysis identified the importance of multiple coupling pathways, circular currents, and pathway interferences.

Proteins are not static structures and the possible role of protein dynamics in modulating long-range couplings has long been of interest. ${ }^{118-119}$ Skourtis examined the role of protein dynamics and non-Condon effects in the reactions of Ru-modified azurin. ${ }^{100}$ On the basis of molecular dynamics simulations, he found that electronic coupling fluctuations are rapid and coupling coherence is lost in tens of femtoseconds. Since this time is roughly an order of magnitude slower than the decay of nuclear Franck-Condon overlaps, it would appear that non-Condon effects play a minor role in these reactions. Notably, based on an analysis of coupling coherence and multiple pathways in Ru-modified cytochrome $b_{562}$, Beratan and coworkers proposed that the structure-sensitivity of long-range couplings depends on the number of dynamically averaged pathways contributing to the D-A interaction. ${ }^{103}$ And, by combining dynamics with $a b$ initio calculations, they obtained very good agreement with experimentally validated couplings for Ru-modified azurins. ${ }^{120}$

\section{Hopping}

Our work has shown that the maximum center-to-center distance for functional single-step tunneling through proteins can be no greater than $\sim 25 \AA$ (Figure 4). The structures of several protein redox complexes, however, suggest that charge transfer may occur over distances that greatly exceed this single-step limit. ${ }^{35,121-123}$ Participation in multistep electron tunneling has been documented in a number of enzymes (ribonucleotide reductase, ${ }^{121-122,124-131}$ photosystem II, ${ }^{132-135}$ DNA photolyase, ${ }^{136-144} \mathrm{MauG}^{145-148}$ and the cytochrome $c /$ cytochrome $c$ peroxidase pair. ${ }^{149-150}$

Modeling the kinetics of electron hopping is a problem that can be solved analytically. ${ }^{35}$ Using the well-defined properties of ET reactions (Eq. 6), and the average distance dependence defined by Ru-protein tunneling timetables, we can predict hopping rates for any set of driving-force, temperature, and distance parameters. Consider a two-step tunneling reaction (Eq. 7) (reactants, $\boldsymbol{R}=\mathbf{D}$-I-

$$
R \underset{k_{H R}}{\stackrel{K_{R H}}{\rightleftarrows}} H \underset{k_{P H}}{\stackrel{k_{H P}}{\rightleftarrows}} P
$$

A; redox intermediate, $\boldsymbol{H}=\mathbf{D}^{+}-\mathbf{I}^{-}-\mathbf{A}$ or $\mathbf{D}-\mathbf{I}^{+}-\mathbf{A}^{-}$; products, $\left.\boldsymbol{P}=\mathbf{D}^{+}-\mathbf{I}-\mathbf{A}^{-}\right)$. The general solution to the rate law for this process calls for biexponential production of $\boldsymbol{P}$, although in some cases $\boldsymbol{P}$ formation can be approximated by a single exponential function. Taking a 
value of $\lambda=0.8 \mathrm{eV}$ for both ET reactions (i.e., $\boldsymbol{R} \rightarrow \boldsymbol{H}$ and $\boldsymbol{H} \rightarrow \boldsymbol{P}$ ) and a decay constant of 1.1 $\AA^{-1}$, we obtain the time dependence of the populations of all three reacting species for values of $\Delta \mathrm{G}^{\circ} \mathbf{R H}, \Delta \mathrm{G}^{\circ} \mathbf{H P}, r_{\mathbf{R H}}$, and $r_{\mathbf{H P}} \cdot{ }^{35}$ Results for $\Delta \mathrm{G}^{\circ}{ }_{\mathbf{R H}}=-\Delta \mathrm{G}^{\circ} \mathbf{H P}$ and $r_{\mathbf{R H}}=r_{\mathbf{H P}}$ are illustrated in Figure 7, a model that can describe biological electron transfer $\left(\Delta \mathrm{G}^{\circ} \mathbf{R P}=0\right)$ with a single endergonic step. Transport across $20 \AA$ is $10^{4}$ times faster than a single tunneling step, and, importantly, submillisecond transfers can be realized at this distance. Note that hopping can facilitate electron flow over distances greater than $20 \AA$ in cases where the free-energy changes for endergonic intermediate steps are no greater than $0.2 \mathrm{eV}$.

We expressed three mutant azurins to see if an intervening tryptophan or tyrosine could facilitate electron transfer between distant metal redox centers. In these mutants, a histidine is at position 124 on the $\beta$ strand extending from Met121, and either tryptophan, tyrosine, or phenylalanine is at 122 . A powerful photosensitizer/oxidant, $\operatorname{Re}^{\mathrm{I}}(\mathrm{CO})_{3}(4,7$-dimethyl-1,10phenanthroline) $\left(\operatorname{Re}^{\mathrm{I}}(\mathrm{CO})_{3}(\mathrm{dmp})\right)$, was attached to His124 ( ${ }^{3} \mathrm{MLCT}$ excited state: $E^{\circ}$ $\left[{ }^{*} \operatorname{Re}^{\mathrm{II}}(\mathrm{CO})_{3}\left(\mathrm{dmp}^{-}-\right)(\operatorname{His} 124) / \operatorname{Re}^{\mathrm{I}}(\mathrm{CO})_{3}\left(\mathrm{dmp}^{\bullet-}\right)(\mathrm{His} 124)\right]=1.4 \mathrm{~V}$ vs. NHE. ${ }^{151}$ In the Relabeled Trp122 variant $\left(\operatorname{Re}^{\mathrm{I}}(\mathrm{CO})_{3}(\mathrm{dmp})(\operatorname{His} 124)|(\operatorname{Trp} 122)| \mathrm{AzCu}^{\mathrm{II}}\right)$, dmp and the Trp122 indole group are near van der Waals contact $(\sim 4 \AA)$, and the $\mathrm{Cu}$-Re distance is $19.4 \AA$ (Figure 8). ${ }^{152}$

Optical excitation of $\operatorname{Re}^{\mathrm{I}}(\mathrm{CO})_{3}(\mathrm{dmp})\left(\right.$ His124) creates a ${ }^{1}$ MLCT excited state, which undergoes $\sim 150$ fs intersystem crossing ${ }^{153}$ to a vibrationally excited triplet $\left({ }^{3} \mathrm{MLCT}\right)$. Subpicosecond generation of $\operatorname{Re}^{\mathrm{I}}(\mathrm{CO})_{3}\left(\mathrm{dmp}^{\bullet-}\right)(\mathrm{His} 124)$ is attributable to ET from Trp122 to the $\operatorname{Re}^{\mathrm{I}}(\mathrm{CO})_{3}(\mathrm{dmp})(\mathrm{His} 124)$ excited singlet ( ${ }^{1}$ MLCT). A 350-ps kinetics phase is due to equilibration between the ${ }^{3} \mathrm{MLCT}$ state and $\operatorname{Re}^{\mathrm{I}}(\mathrm{CO})_{3}\left(\mathrm{dmp}^{\bullet-}\right)(\mathrm{His} 124)\left|(\operatorname{Trp} 122)^{\bullet+}\right| \mathrm{AzCu}^{\mathrm{I}}$, followed by 30-ns reduction of (Trp122) $)^{\bullet+}$ by $\mathrm{AzCu}^{\mathrm{I}}$ to generate $\mathrm{Re}^{\mathrm{I}}(\mathrm{CO})_{3}\left(\mathrm{dmp}^{\bullet-}\right)(\mathrm{His} 124)$ (Trp122) $\mathrm{AzCu}^{\mathrm{II}}$. Ground-state repopulation occurs in $3 \mu$ s via single-step ET from $\operatorname{Re}^{\mathrm{I}}(\mathrm{CO})_{3}\left(\mathrm{dmp}^{\cdot-}\right)\left(\right.$ His 124) to $\mathrm{AzCu}^{\mathrm{II}}$ (Figure 9). Rate constants were calculated for elementary reaction steps assuming a two-step kinetics model.

Most importantly, we demonstrated that $\mathrm{Cu}^{\mathrm{I}}$ oxidation in $\mathrm{Re}^{\mathrm{I}}(\mathrm{CO})_{3}(\mathrm{dmp})(\operatorname{His} 124)|(\operatorname{Trp} 122)|$ $\mathrm{AzCu}^{\mathrm{I}}$ is orders of magnitude faster than expected for electron tunneling over $19 \AA$ A. In our analysis, the reduction potential of $* \operatorname{Re}^{\mathrm{II}}(\mathrm{CO})_{3}\left(\mathrm{dmp}^{*-}\right)($ His 124) is just $28 \mathrm{mV}$ greater than that of $(\operatorname{Trp} 122)^{\bullet+/ 0}$, but very rapid $(\sim$ ns) ET between adjacent dmp and Trp122 aromatic rings occurs even at this small driving force. Replacement of Trp122 by Tyr or Phe inhibits the initial ET event, as predicted, because the $(\mathrm{Tyr} 122)^{\bullet+/ 0}$ and $(\mathrm{Phe} 122)^{\circ+/ 0}$ potentials are $200 \mathrm{mV}$ above $E^{\circ}\left(* \operatorname{Re}^{\mathrm{II}} / \operatorname{Re}^{\mathrm{I}}(\mathrm{CO})_{3}\left(\mathrm{dmp}^{*-}\right)(\right.$ His 124) $)$. Concerted oxidation and deprotonation of Tyr122 by $* \operatorname{Re}^{\mathrm{II}}(\mathrm{CO})_{3}\left(\mathrm{dmp}^{*-}\right)$ (His 124) could be thermodynamically favorable, but likely would have an activation barrier. We conclude that deprotonation of the Trp radical cation, a relatively weak acid $\left(p K_{\mathrm{a}}=4.5(2)\right),{ }^{154-155}$ is slower ${ }^{144}$ than oxidation of $\mathrm{Cu}^{\mathrm{I}}$ in the protein.

A hopping map for $\operatorname{Re}^{\mathrm{I}}(\mathrm{CO})_{3}(\mathrm{dmp})(\mathrm{His} 124)|(\operatorname{Trp} 122)| \mathrm{AzCu}^{\mathrm{I}}$ is shown in Figure 10. The bounded region corresponds to driving-force regimes in which two-step hopping is faster than single-step tunneling. We note that the overall charge separation rate is more sensitive to the free-energy change for the first of the two tunneling steps. Indeed, the rate advantage of the multistep process is lost if the first tunneling step is too endergonic $\left(\Delta \mathrm{G}^{\circ}(\mathrm{Int} \rightarrow * \mathrm{ML})\right.$ $>200 \mathrm{meV}) .{ }^{35,156}$ The map predicts a $\sim 100$-ns time constant for $\mathrm{Cu}^{\mathrm{I}}$ oxidation, in reasonable accord with the experimental value of $\sim 30 \mathrm{~ns}$.

A different type of map (Figure 11) can be employed to design electron hopping systems. ${ }^{157}$ We have used these maps to identify potential locations for redox intermediates (Int) in three Ru-modified azurins (Ru-H107, Ru-H124, and Ru-H126). The maps compare the total ET times for hopping from a donor (D) to an intermediate (I) to an acceptor (A) ( $\tau_{\text {hop }}$ ) versus times for single-step D to A tunneling ( $\tau s s)$. In all cases, the greatest hopping advantage 
occurs in systems where the Int- $\mathrm{Ru}^{\mathrm{III}}$ distance is 0 to $5 \AA$ shorter than that for Int-Cu . The hopping advantage increases as systems orient nearer a "straight-line" between the donor and acceptor (the black diagonal), which is a result of minimizing intermediate tunneling distances. The smallest predicted hopping advantage area is in Ru-H124 azurin, which has the shortest $\mathrm{Ru}-\mathrm{Cu}$ distance of the three proteins.

The maps in Figure 11 illustrate how the hopping advantage at a fixed D-A distance changes as a function of driving force $\left(-\Delta G^{\circ}\right)$. The hopping advantage is nearly lost as the driving force for the first step $\left(\mathrm{Ru}^{\mathrm{III}} \leftarrow\right.$ Int) falls below $-0.15 \mathrm{eV}$. Isoergic initial steps give a wide distribution of arrangements, where advantages as great as $10^{4}$ are possible (for a fixed donor-acceptor distance of 23.7 or $25.4 \AA$ ). A slightly exergonic $\mathrm{Ru}^{\mathrm{III}} \leftarrow$ Int step provides an even larger distribution of arrangements for productive hopping, which will be the case as long as the driving force for the first step is not more favorable than that for the overall electron transfer.

In recent work, we employed nitrotyrosinate $\left(\mathrm{NO}_{2} \mathrm{YO}^{-}\right)$as a redox intermediate in the three $\mathrm{Ru}$-His labeled azurins to test the hopping advantage for net $\mathrm{Cu}^{\mathrm{I}} \rightarrow \mathrm{Ru}^{\mathrm{III}}$ ET. The phenol $\mathrm{p} K_{\mathrm{a}}$ of 3-nitrotyrosine is 7.2, permitting measurements at near-neutral $\mathrm{pH}$ rather than the high $\mathrm{pH}$ values $(>10)$ required to study analogous reactions in tyrosine. Stubbe and coworkers employed a similar strategy using fluorinated Y residues to characterize the radical transfer pathway in ribonucleotide reductase. ${ }^{158-159}$ Hopping ET via nitrotyrosinate also avoids the complexities associated with the kinetics of proton-coupled redox reactions of tyrosine. Mutant azurins were prepared with $\mathrm{NO}_{2} \mathrm{YO}^{-}$situated between the $\mathrm{Ru}$ and $\mathrm{Cu}$ sites: $\mathrm{RuH} 107 \mathrm{NO}_{2} \mathrm{YOH} 109 ; \mathrm{RuH} 124 \mathrm{NO}_{2} \mathrm{YOH} 122$; and RuH126NO $\mathrm{NOH}_{2} 22$. The first two systems have cofactor placements that are close to optimal; the last system has a larger first-step distance, which is predicted to decrease the hopping advantage.

Specific rates of $\mathrm{Cu}^{\mathrm{I}}$ oxidation in the three proteins were more than 10 times greater than those of single-step ET in the corresponding azurins lacking $\mathrm{NO}_{2} \mathrm{YOH}$ (107 or 122), confirming that $\mathrm{NO}_{2} \mathrm{YO}^{-}$accelerates long-range ET. Using structural data along with estimates of potentials, hopping maps were constructed to provide insights into $\mathrm{NO}_{2} \mathrm{YO}^{-}$meditated intraprotein ET (Figure 12). Here the proposed reaction sequence is [ $\mathrm{Ru}^{\mathrm{III}}$ $\left.\mathrm{NO}_{2} \mathrm{YO}^{-}-\mathrm{Cu}^{\mathrm{I}}\right] \rightarrow\left[\mathrm{Ru}^{\mathrm{II}}-\mathrm{NO}_{2} \mathrm{YO}^{-}-\mathrm{Cu}^{\mathrm{I}}\right] \rightarrow\left[\mathrm{Ru}^{\mathrm{II}}-\mathrm{NO}_{2} \mathrm{YO}^{-}-\mathrm{Cu}^{\mathrm{II}}\right]$, although the nitrotyrosyl radical intermediate has not been detected by transient spectroscopy in any of the proteins investigated. The hopping maps predict electron transport times that are in good agreement with experimentally determined rate constants. Importantly, we found that a $100-200 \mathrm{meV}$ endergonic intermediate redox step with $\mathrm{NO}_{2} \mathrm{YO}^{-}$accelerates long-range ET by more than 10-fold.

\section{New Directions}

In addition to providing fundamental insights into long-range ET processes, $\mathrm{Ru}$ and Remodified proteins have found important applications in studies of enzyme mechanisms. Cytochrome $c$ oxidase was an early target, ${ }^{160}$ wherein a Ru-modified cytochrome $c$ was used to inject electrons into the oxidized enzyme, and the flow of electrons was monitored by transient spectroscopy. In this study, results from time-resolved electrometry following electron injection into cytochrome oxidase from Ru-modified cytochrome $c$ shed light on the dynamics of charge migration and proton pumping in the enzyme. ${ }^{161}$

Most efforts to trap highly oxidized intermediates in cytochrome P450 catalysis have been frustrated by rate-limiting formation of products as well as rapid enzyme decomposition. ${ }^{162}$ Promising results, however, were obtained when we found that horseradish peroxidase compounds I and II could be generated by sequential oxidation of the ferric enzyme with 
$\mathrm{Ru}(\mathrm{bpy}) 3^{3+}{ }^{363}$ But the analogous approach was unsuccessful with cytochrome P450, presumably because the heme is more deeply buried within the polypeptide matrix. We fixed this problem by covalently coupling a Ru-diimine to a surface cysteine on a P450 BM3 mutant; laser flash-quench generation of $\mathrm{Ru}(\mathrm{III})$ was followed by production of compound II in this structurally characterized Ru-modified P450 BM3 ${ }^{164}$ In subsequent work, Cheruzel and coworkers reported that this Ru-modified P450 is an active photocatalyst for the hydroxylation of lauric acid. ${ }^{165}$

The mechanism of nitrogen reduction to ammonia catalyzed by the nitrogenase enzyme has attracted much interest since the original measurement of the $\mathrm{N}_{2}$ dissociation constant by Lineweaver, Burk, and Deming in $1934 .{ }^{166}$ Efforts to elucidate the details of the eightelectron, eight-proton hydrogenase/nitrogenase reaction continue to this day. ${ }^{167}$ Very recently, Tezcan and coworkers have employed a Ru-modified enzyme to inject electrons into the active site of the MoFe protein, catalyzing the six-electron reduction of $\mathrm{HCN}$ to $\mathrm{CH}_{4}$ and possibly $\mathrm{NH}_{3}$ as well. ${ }^{168}$ A very important finding is that the Ru-modified enzyme can catalyze these multielectron reduction reactions without the assistance of ATP.

\section{Literature Cited}

1. Dodson RW. J. Am. Chem. Soc. 1950; 72:3315.

2. Thompson RC. J. Am. Chem. Soc. 1948; 70:1045.

3. Gryder JW, Dodson RW. J. Am. Chem. Soc. 1949; 71:1894.

4. Cobble JW, Adamson AW. J. Am. Chem. Soc. 1950; 72:2276.

5. Hornig HC, Zimmerman GL, Libby WF. J. Am. Chem. Soc. 1950; 72:3808.

6. Bonner NA, Potratz HA. J. Am. Chem. Soc. 1951; 73:1845.

7. Harbottle G, Dodson RW. J. Am. Chem. Soc. 1951; 73:2442.

8. Meier DJ, Garner CS. J. Am. Chem. Soc. 1951; 73:1894.

9. Silverman J, Dodson RW. J. Phys. Chem. 1952; 56:846.

10. Libby WF. J. Phys. Chem. 1952; 56:863.

11. Marcus RJ, Zwolinski BJ, Eyring H. J. Phys. Chem. 1954; 58:432.

12. Zwolinski BJ, Marcus RJ, Eyring H. Chem. Rev. 1955; 55:157.

13. Marcus RA. J. Chem. Phys. 1956; 24:966.

14. Hopfield JJ. Proc. Natl. Acad. Sci. USA. 1974; 71:3640. [PubMed: 16592178]

15. Winkler JR, Nocera DG, Yocom KM, Bordignon E, Gray HB. J. Am. Chem. Soc. 1982; 104:5798.

16. McGourty JL, Blough NV, Hoffman BM. J. Am. Chem. Soc. 1983; 105:4470.

17. Calcaterra LT, Closs GL, Miller JR. J. Am. Chem. Soc. 1983; 105:670.

18. Freed KF. Chem. Phys. Lett. 1983; 97:489.

19. Overfield RE, Scherz A, Kaufmann KJ, Wasielewski MR. J. Am. Chem. Soc. 1983; 105:5747.

20. Simolo KP, McLendon GL, Mauk MR, Mauk AG. J. Am. Chem. Soc. 1984; 106:5012.

21. Gunner MR, Robertson DE, Dutton PL. J. Phys. Chem. 1986; 90:3783.

22. Kuki A, Wolynes PG. Science. 1987; 236:1647. [PubMed: 3603005]

23. Closs GL, Miller JR. Science. 1988; 240:440. [PubMed: 17784065]

24. Heitele H, Finckh P, Weeren S, Pöllinger F, Michel-Beyerle ME. J. Phys. Chem. 1989; 93:5173.

25. Lawson JM, Craig DC, Paddon-Row MN, Kroon J, Verhoeven JW. Chem. Phys. Lett. 1989; 164:120.

26. Moser CC, Keske JM, Warncke K, Farid RS, Dutton PL. Nature. 1992; 355:796. [PubMed: 1311417]

27. Wasielewski MR. Chem. Rev. 1992; 92:435.

28. Evenson JW, Karplus M. Science. 1993; 262:1247. [PubMed: 8235654]

29. Gray HB, Winkler JR. Annu. Rev. Biochem. 1996; 65:537. [PubMed: 8811189] 
30. Kuznetsov, AM.; Ulstrup, J. Electron Transfer in Chemistry and Biology: An Introduction to the Theory. Hoboken, NJ: John Wiley \& Sons, Inc; 1998.

31. Skourtis SS, Beratan DN. Curr. Opin. Chem. Biol. 1998; 2:235. [PubMed: 9667934]

32. Verhoeven JW. Adv. Chem. Phys. 1999; 106:603.

33. Winkler JR. Curr. Opin. Chem. Biol. 2000; 4:192. [PubMed: 10742192]

34. Gray, HB.; Winkler, JR. Electron Transfer in Chemistry. Balzani, V., editor. Vol. Vol. III. WileyVCH: Weinheim; 2001.

35. Gray HB, Winkler JR. Quart. Rev. Biophys. 2003; 36:341.

36. Paddon-Row MN. Aust. J. Chem. 2003; 56:729.

37. Marcus RA, Sutin N. Biochim. Biophys. Acta. 1985; 811:265.

38. Sutin N. Progr. Inorg. Chem. 1983; 30:441.

39. Brunschwig BS, Creutz C, Macartney DH, Sham TK, Sutin N. Faraday Discuss. 1982; 74:113.

40. Gray HB, Malmström BG, Williams RJP. J. Biol. Inorg. Chem. 2000; 5:551. [PubMed: 11085645]

41. Simonson T, Brooks CL. J. Am. Chem. Soc. 1996; 118:8452.

42. Winkler JR, Wittung-Stafshede P, Leckner J, Malmström BG, Gray HB. Proc. Natl. Acad. Sci. USA. 1997; 94:4246. [PubMed: 9113974]

43. Mines GA, Bjerrum MJ, Hill MG, Casimiro DR, Chang I-J, Winkler JR, Gray HB. J. Am. Chem. Soc. 1996; 118:1961.

44. Di Bilio AJ, Hill MG, Bonander N, Karlsson BG, Villahermosa RM, Malmström BG, Winkler JR, Gray HB. J. Am. Chem. Soc. 1997; 119:9921.

45. Brzezinski P. Biochemistry. 1996; 35:5611. [PubMed: 8639518]

46. Farver O, Grell E, Ludwig B, Michel H, Pecht I. Biophys. J. 2006; 90:2131. [PubMed: 16387770]

47. Ramirez BE, Malmström BG, Winkler JR, Gray HB. Proc. Natl. Acad. Sci. USA. 1995; 92:11949. [PubMed: 8618820]

48. Babini E, Bertini I, Borsari M, Capozzi F, Luchinat C, Zhang X, Moura GLC, Kurnikov IV, Beratan DN, Ponce A, Di Bilio AJ, Winkler JR, Gray HB. J. Am. Chem. Soc. 2000; 122:4532.

49. Newton MD. Chem. Rev. 1991; 91:767.

50. Langen R, Chang I-J, Germanas JP, Richards JH, Winkler JR, Gray HB. Science. 1995; 268:1733. [PubMed: 7792598]

51. Regan JJ, Di Bilio AJ, Langen R, Skov LK, Winkler JR, Gray HB, Onuchic JN. Chem. Biol. 1995; 2:489. [PubMed: 9383451]

52. Winkler JR, Di Bilio A, Farrow NA, Richards JH, Gray HB. Pure Appl. Chem. 1999; 71:1753.

53. Winkler JR, Gray HB. Chem. Rev. 1992; 92:369.

54. Adman ET. Adv. Protein Chem. 1991; 42:145. [PubMed: 1793005]

55. Crane BR, Di Bilio AJ, Winkler JR, Gray HB. J. Am. Chem. Soc. 2001; 123:11623. [PubMed: 11716717]

56. Smalley JF, Feldberg SW, Chidsey CED, Linford MR, Newton MD, Liu Y-P. J. Phys. Chem. 1995; 99:13141.

57. Smalley JF, Finklea HO, Chidsey CED, Linford MR, Creager SE, Ferraris JP, Chalfant K, Zawodzinsk T, Feldberg SW, Newton MD. J. Am. Chem. Soc. 2003; 125:2004. [PubMed: 12580629]

58. Farver O, Pecht I. Adv. Chem. Phys. 1999; 107:555.

59. Schlag EW, Sheu SY, Yang DY, Selzle HL, Lin SH. Angew. Chem., Int. Ed. Eng. 2007; 46:3196.

60. Chang I-J, Gray HB, Winkler JR. J. Am. Chem. Soc. 1991; 113:7056.

61. Tominaga K, Kliner DAV, Johnson AE, Levinger NE, Barbara PF. J. Chem. Phys. 1993; 98:1228.

62. Son DH, Kambhampati P, Kee TW, Barbara PF. J. Phys. Chem. A. 2002; 106:4591.

63. Brunschwig BS, Creutz C, Sutin N. Chem. Soc. Rev. 2002; 31:168. [PubMed: 12122642]

64. Weaver MJ. Chem. Rev. 1992; 92:463.

65. Vance FW, Slone RV, Stern CL, Hupp JT. Chem. Phys. 2000; 253:313.

66. Billing R, Khoshtariya DE. Inorg. Chem. 1994; 33:4038.

67. Figgis BN, Kucharski ES, Raynes JM, Reynolds PA. J. Chem. Soc., Dalton Trans. 1990:3597. 
68. Figgis BN, Reynolds PA, Sobolev AN. J. Chem. Soc., Dalton Trans. 1994:1429.

69. Ponnu A, Sung JH, Spears KG. J. Phys. Chem. A. 2006; 110:12372. [PubMed: 17091938]

70. Wenger OS, Leigh BS, Villahermosa RM, Gray HB, Winkler JR. Science. 2005; 307:99. [PubMed: 15637275]

71. Balzani, V., editor. Electron Transfer in Chemistry. Vol. Vol. I-V. Wiley-VCH: Weinheim; 2001.

72. Fox LS, Kozik M, Winkler JR, Gray HB. Science. 1990; 247:1069. [PubMed: 17800065]

73. Elliott CM, Derr DL, Matyushov DV, Newton MD. J. Am. Chem. Soc. 1998; 120:11714.

74. Closs GL, Calcaterra LT, Green NJ, Penfield KW, Miller JR. J. Phys. Chem. 1986; 90:3673.

75. Hush NS. Electrochim. Acta. 1968; 13:1005.

76. Stein CA, Taube H. J. Am. Chem. Soc. 1981; 103:693.

77. Creutz C. Progr. Inorg. Chem. 1983; 30:1.

78. Nelsen SF, Ismagilov RF, Teki Y. J. Am. Chem. Soc. 1998; 120:2200.

79. Creutz C, Newton MD, Sutin N. Journal of Photochemistry and Photobiology a-Chemistry. 1994; 82:47.

80. Distefano AJ, Wishart JF, Isied SS. Coord. Chem. Rev. 2005; 249:507.

81. Hudis J, Dodson RW. J. Am. Chem. Soc. 1956; 78:911.

82. Friedman HL, Newton MD. Faraday Discuss. 1982; 74:73.

83. Logan J, Newton MD. J. Chem. Phys. 1983; 78:4086.

84. Brunschwig BS, Logan J, Newton MD, Sutin N. J. Am. Chem. Soc. 1980; 102:5798.

85. Tembe BL, Friedman HL, Newton MD. J. Chem. Phys. 1982; 76:1490.

86. Bader JS, Kuharski RA, Chandler D. J. Chem. Phys. 1990; 93:230.

87. Kuharski RA, Bader JS, Chandler D, Sprik M, Klein ML, Impey RW. J. Chem. Phys. 1988; $89: 3248$.

88. Friedman HL, Newton MD. J. Electroanal. Chem. 1986; 204:21.

89. Churg AK, Weiss RM, Warshel A, Takano T. The Journal of Physical Chemistry. 1983; 87:1683.

90. Olsson MHM, Ryde U, Roos BO. Prot. Sci. 1998; 7:2659.

91. Ryde U, Olsson MHM. Int. J. Quant. Chem. 2001; 81:335.

92. Sigfridsson E, Olsson MHM, Ryde U. J. Phys. Chem. B. 2001; 105:5546.

93. Skourtis SS, Beratan DN. J. Biol. Inorg. Chem. 1997; 2:378.

94. Beratan DN, Betts JN, Onuchic JN. Science. 1991; 252:1285. [PubMed: 1656523]

95. Beratan DN, Onuchic JN. Photosynth. Res. 1989; 22:173. [PubMed: 24424807]

96. Onuchic JN, Beratan DN, Winkler JR, Gray HB. Annu. Rev. Biophys. Biomol. Struct. 1992; 21:349. [PubMed: 1326356]

97. Beratan DN, Onuchic JN, Winkler JR, Gray HB. Science. 1992; 258:1740. [PubMed: 1334572]

98. Balabin IA, Onuchic JN. J. Phys. Chem. B. 1998; 102:7497.

99. Kumar K, Kurnikov IV, Beratan DN, Waldeck DH, Zimmt MB. J. Phys. Chem. A. 1998; 102:5529.

100. Skourtis SS, Balabin I, Kawatsu T, Beratan DN. Proc. Natl. Acad. Sci. USA. 2005; 102:3552. [PubMed: 15738409]

101. Lin JP, Balabin IA, Beratan DN. Science. 2005; 310:1311. [PubMed: 16311331]

102. Kawatsu T, Beratan DN, Kakitani T. J. Phys. Chem. B. 2006; 110:5747. [PubMed: 16539520]

103. Prytkova TR, Kurnikov IV, Beratan DN. Science. 2007; 315:622. [PubMed: 17272715]

104. Balabin IA, Beratan DN, Skourtis SS. Phys. Rev. Lett. 2008:101.

105. Regan JJ, Onuchic JN. Adv. Chem. Phys. 1999; 107:497.

106. Tan ML, Balabin I, Onuchic JN. Biophys. J. 2004; 86:1813. [PubMed: 14990507]

107. Onuchic JN, Kobayashi C, Baldridge KK. J. Braz. Chem. Soc. 2008; 19:206.

108. Skourtis SS, Beratan DN. J. Phys. Chem. B. 1997; 101:1215.

109. Stuchebrukhov AA. Theor. Chem. Acc. 2003; 110:291.

110. Zheng XH, Georgievskii Y, Stuchebrukhov AA. J. Chem. Phys. 2004; 121:8680. [PubMed: 15527331] 
111. Zheng XH, Medvedev DM, Stuchebrukhov AA. Int. J. Quant. Chem. 2005; 102:473.

112. Stuchebrukhov AA. J. Chem. Phys. 1996; 105:10819.

113. Stuchebrukhov AA. J. Chem. Phys. 1996; 104:8424.

114. Stuchebrukhov AA. J. Chem. Phys. 1997; 107:6495.

115. Stuchebrukhov AA. J. Chem. Phys. 1998; 108:8499.

116. Stuchebrukhov AA. J. Chem. Phys. 1998; 108:8510.

117. Gehlen JN, Daizadeh I, Stuchebrukhov AA, Marcus RA. Inorg. Chim. Acta. 1996; 243:271.

118. Dogonadze RR, Kuznetsov AM, Ulstrup J. J. Theoret. Biol. 1977; 69:239. [PubMed: 592874]

119. Kuznetsov, AM.; Ulstrup, J.; Zakaraya, MG. Perspectives in Photosynthesis. Jortner, J.; Pullman, B., editors. Vol. Vol. 22. 1990.

120. Prytkova TR, Kurnikov IV, Beratan DN. J. Phys. Chem. B. 2005; 109:1618. [PubMed: 16851133]

121. Sjöberg BM. Struct. Bonding. 1997; 88:139.

122. Stubbe J, Nocera DG, Yee CS, Chang MCY. Chem. Rev. 2003; 103:2167. [PubMed: 12797828]

123. Page CC, Moser CC, Chen X, Dutton PL. Nature. 1999; 402:47. [PubMed: 10573417]

124. Stubbe J, van der Donk WA. Chem. Rev. 1998; 98:705. [PubMed: 11848913]

125. Argirevic T, Riplinger C, Stubbe J, Neese F, Bennati M. J. Am. Chem. Soc. 2012; 134:17661. [PubMed: 23072506]

126. Holder PG, Pizano AA, Anderson BL, Stubbe J, Nocera DG. J. Am. Chem. Soc. 2012; 134:1172. [PubMed: 22121977]

127. Offenbacher AR, Minnihan EC, Stubbe J, Barry BA. J. Am. Chem. Soc. 2013; 135:6380. [PubMed: 23594029]

128. Worsdorfer B, Conner DA, Yokoyama K, Livada J, Seyedsayamdost M, Jiang W, Silakov A, Stubbe J, Bollinger JM, Krebs C. J. Am. Chem. Soc. 2013; 135:8585. [PubMed: 23676140]

129. Yokoyama K, Smith AA, Corzilius B, Griffin RG, Stubbe J. J. Am. Chem. Soc. 2011; 133:18420. [PubMed: 21967342]

130. Offenbacher AR, Burns LA, Sherrill CD, Barry BA. J. Phys. Chem. B. 2013; 117:8457. [PubMed: 23822111]

131. Chang MCY, Yee CS, Nocera DG, Stubbe J. J. Am. Chem. Soc. 2004; 126:16702. [PubMed: 15612690]

132. Boussac A, Rappaport F, Brettel K, Sugiura M. J. Phys. Chem. B. 2013; 117:3308. [PubMed: 23448315]

133. Keough JM, Zuniga AN, Jenson DL, Barry BA. J. Phys. Chem. B. 2013; 117:1296. [PubMed: 23346921]

134. Sjoholm J, Styring S, Havelius KGV, Ho FM. Biochemistry. 2012; 51:2054. [PubMed: 22352968]

135. Tommos C, Babcock GT. Biochim. Biophys. Acta - Bioenerg. 2000; 1458:199.

136. Sancar A. Chem. Rev. 2003; 103:2203. [PubMed: 12797829]

137. Taylor JS. Acc. Chem. Res. 1994; 27:76.

138. Li YF, Heelis PF, Sancar A. Biochemistry. 1991; 30:6322. [PubMed: 2059637]

139. Aubert C, Mathis P, Eker APM, Brettel K. Proc. Natl. Acad. Sci. USA. 1999; 96:5423. [PubMed: 10318899]

140. Byrdin M, Eker APM, Vos MH, Brettel K. Proc. Natl. Acad. Sci. USA. 2003; 100:8676. [PubMed: 12835419]

141. Kodali G, Siddiqui SU, Stanley RJ. J. Am. Chem. Soc. 2009; 131:4795. [PubMed: 19292445]

142. Lukacs A, Eker APM, Byrdin M, Villette S, Pan J, Brettel K, Vos MH. J. Phys. Chem. B. 2006; 110:15654. [PubMed: 16898706]

143. Woiczikowski PB, Steinbrecher T, Kubar T, Elstner M. J. Phys. Chem. B. 2011; 115:9846. [PubMed: 21793510]

144. Aubert C, Vos MH, Mathis P, Eker APM, Brettel K. Nature. 2000; 405:586. [PubMed: 10850720] 
145. Davidson VL, Liu AM. Biochim Biophys Acta - Proteins Proteomics. 2012; 1824:1299.

146. Geng JF, Dornevil K, Davidson VL, Liu AM. Proc. Natl. Acad. Sci. USA. 2013; 110:9639. [PubMed: 23720312]

147. Yukl ET, Liu FG, Krzystek J, Shin S, Jensen LMR, Davidson VL, Wilmot CM, Liu AM. Proc. Natl. Acad. Sci. USA. 2013; 110:4569. [PubMed: 23487750]

148. Davidson VL, Wilmot CM. Annu. Rev. Biochem. 2013; 82:531. [PubMed: 23746262]

149. Jiang N, Kuznetsov A, Nocek JM, Hoffman BM, Crane BR, Hu XQ, Beratan DN. J. Phys. Chem. B. 2013; 117:9129. [PubMed: 23895339]

150. Seifert JL, Pfister TD, Nocek JM, Lu Y, Hoffman BM. J. Am. Chem. Soc. 2005; 127:5750. [PubMed: 15839648]

151. Connick WB, Di Bilio AJ, Hill MG, Winkler JR, Gray HB. Inorg. Chim. Acta. 1995; 240:169.

152. Shih C, Museth AK, Abrahamsson M, Blanco-Rodriguez AM, Di Bilio AJ, Sudhamsu J, Crane BR, Ronayne KL, Towrie M, Vlcek A, Richards JH, Winkler JR, Gray HB. Science. 2008; 320:1760. [PubMed: 18583608]

153. Cannizzo A, Blanco-Rodríguez AM, Nahhas A, SŠebera J, Záliš S, Vlček A Jr, Chergui M. J. Am. Chem. Soc. 2008; 130:8967. [PubMed: 18570416]

154. Harriman A. J. Phys. Chem. 1987; $91: 6102$.

155. Solar S, Getoff N, Surdhar PS, Armstrong DA, Singh A. J. Phys. Chem. 1991; 95:3639.

156. Gray HB, Winkler JR. Proc. Natl. Acad. Sci. USA. 2005; 102:3534. [PubMed: 15738403]

157. Warren JJ, Herrera N, Hill MG, Winkler JR, Gray HB. J. Am. Chem. Soc. 2013; 135:11151. [PubMed: 23859602]

158. Seyedsayamdost MR, Yee CS, Reece SY, Nocera DG, Stubbe J. J. Am. Chem. Soc. 2006; 128:1562. [PubMed: 16448127]

159. Seyedsayamdost MR, Yee CS, Stubbe J. Biochemistry. 2010; 50:1403. [PubMed: 21182280]

160. Durham B, Millett F. Biochim. Biophys. Acta - Bioenerg. 2012; 1817:567.

161. Verkhovsky MI, Tuukkanen A, Backgren C, Puustinen A, Wikstrom M. Biochemistry. 2001; 40:7077. [PubMed: 11401552]

162. Rittle J, Green MT. Science. 2010; 330:933. [PubMed: 21071661]

163. Berglund J, Pascher T, Winkler JR, Gray HB. J. Am. Chem. Soc. 1997; 119:2464.

164. Ener ME, Lee YT, Winkler JR, Gray HB, Cheruzel L. Proc. Natl. Acad. Sci. USA. 2010; 107:18783. [PubMed: 20947800]

165. Tran NH, Huynh N, Bui T, Nguyen Y, Huynh P, Cooper ME, Cheruzel LE. Chem. Comm. 2011; 47:11936. [PubMed: 21975564]

166. Lineweaver H, Burk D, Deming WE. J. Am. Chem. Soc. 1934; 56:225.

167. Hoffman BM, Lukoyanov D, Dean DR, Seefeldt LC. Acc. Chem. Res. 2013; 46:587. [PubMed: 23289741]

168. Roth LE, Tezcan FA. J. Am. Chem. Soc. 2012; 134:8416. [PubMed: 22564208]

\section{Biographies}

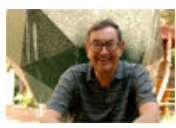

H. B. Gray

After completing a doctoral thesis on inorganic reaction mechanisms at Northwestern and working on ligand field theory as a postdoc in Copenhagen, Harry Gray joined the chemistry faculty at Columbia University, where in the early 1960s he investigated the electronic structures of metal complexes. He moved to Caltech in 1966, where he is the Arnold O. Beckman Professor of Chemistry and the Founding Director of the Beckman Institute. He 
works with students and postdocs on problems in inorganic photochemistry and biological inorganic chemistry.

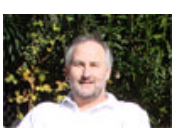

\section{J. R. Winkler}

Jay R. Winkler received a B.S. in chemistry from Stanford University in 1978 and a Ph.D. from Caltech in 1984, where he worked with Harry Gray. After carrying out postdoctoral work with Norman Sutin and Thomas Netzel at Brookhaven National Laboratory, he was appointed to the scientific staff in the Brookhaven Chemistry Department. In 1990 he moved to Caltech, where he is currently the Director of the Beckman Institute Laser Resource Center, Member of the Beckman Institute, and a Faculty Associate in Chemistry. 


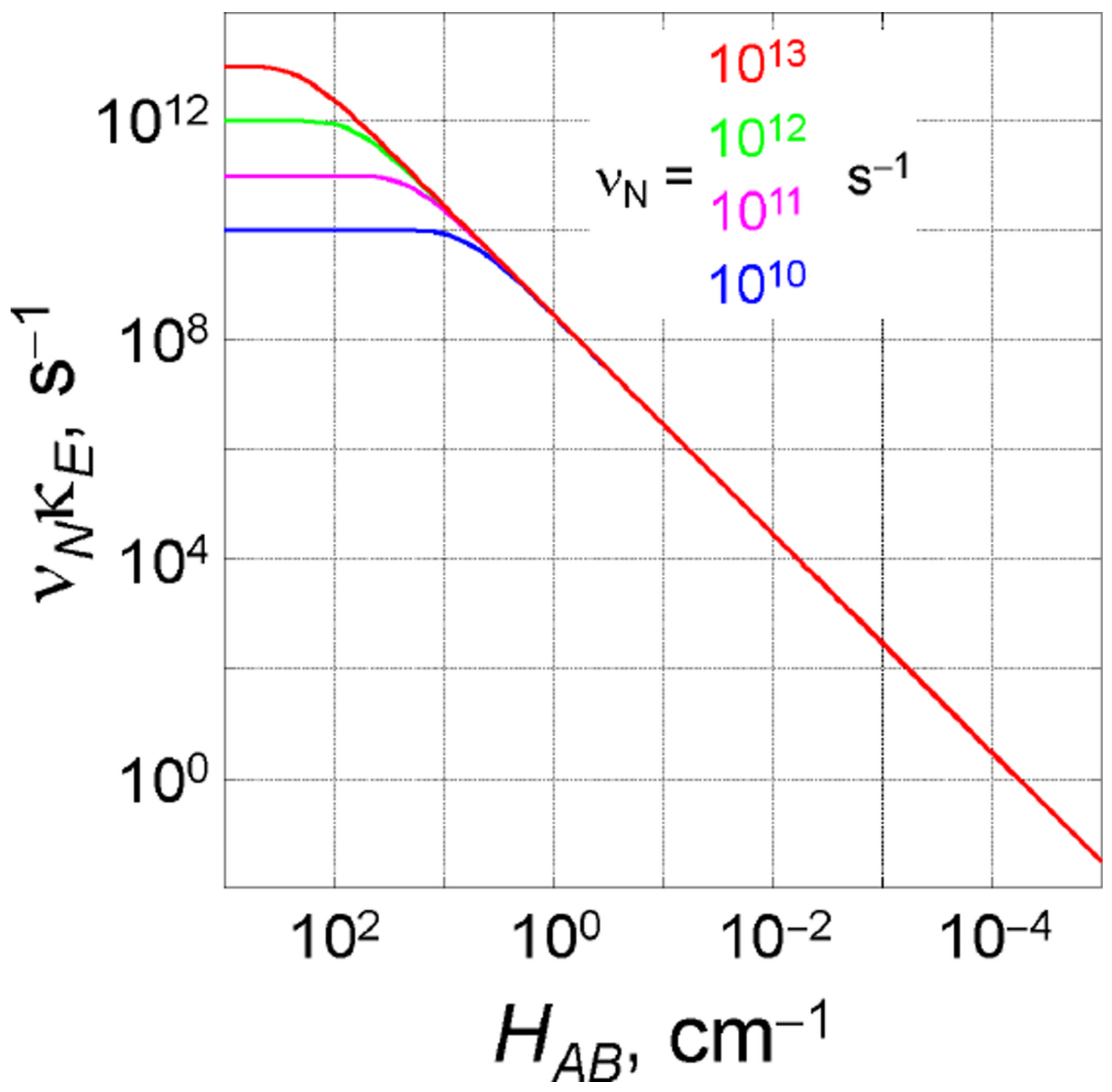

Figure 1.

Variation of the maximum ET rate constant $\left(v_{N} \kappa_{E}\right)$ as a function $H_{A B}$ (Eqs. 4,5) for different values of $v_{N}$ between $10^{10}$ and $10^{13} \mathrm{~s}^{-1}$. 

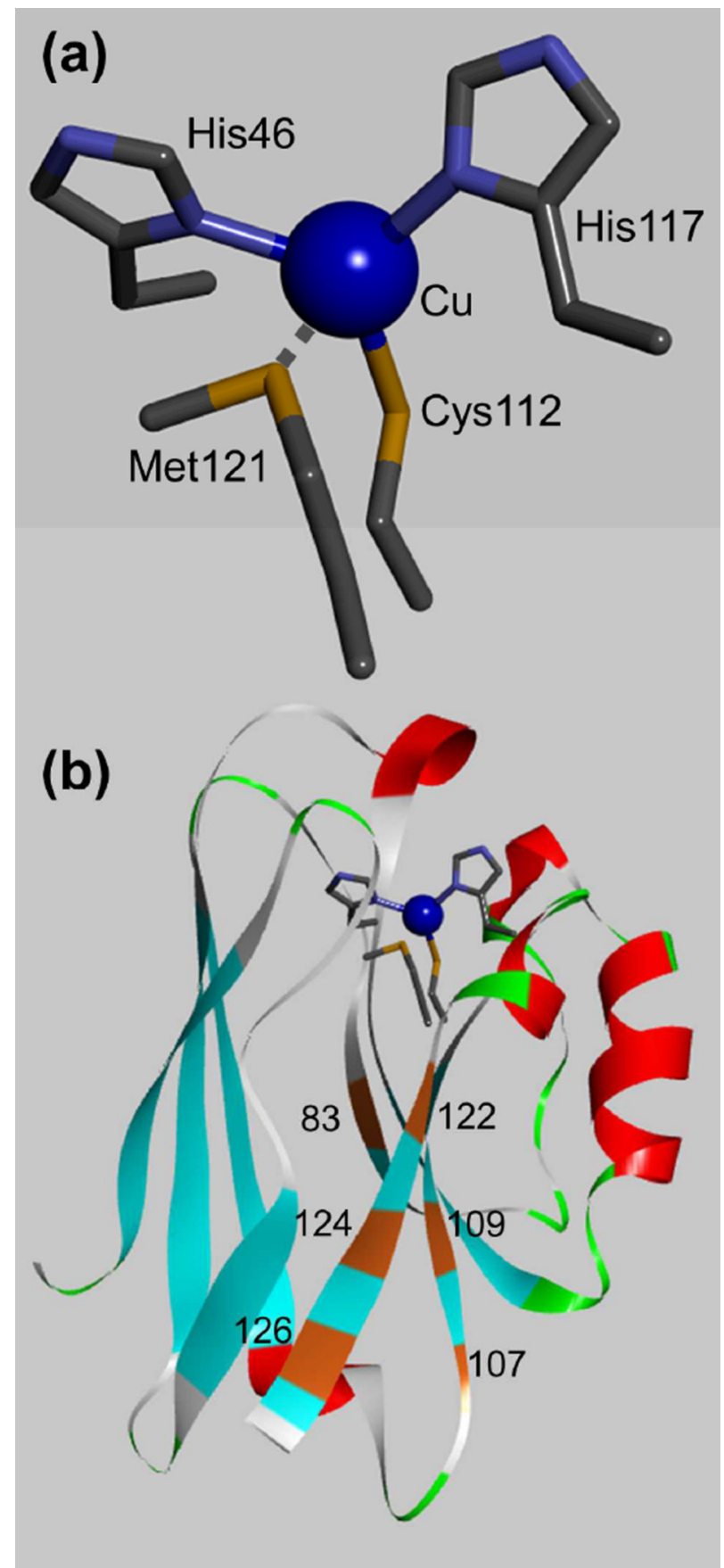

Figure 2.

Structural models of Pseudomonas aeruginosa azurin (PDB \# 1E5Z). (a) copper coordination geometry; (b) ribbon structure of the polypeptide backbone, highlighting (orange) the sites of Ru-modification. 


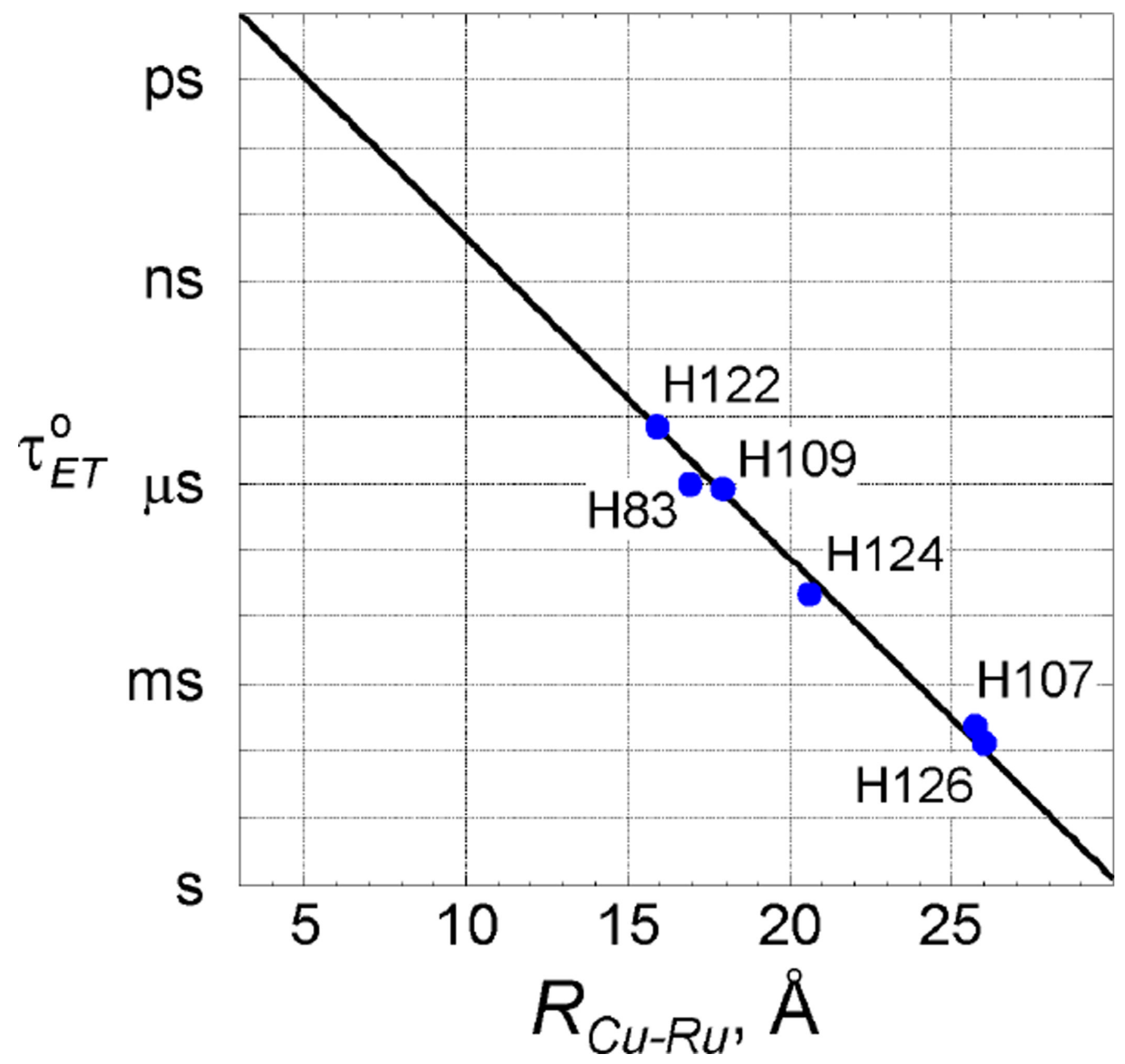

Figure 3.

Distance dependence of driving-force optimized tunneling times, $\tau_{E T}^{\mathrm{o}}=\left(k_{E T}^{\mathrm{o}}\right)^{-1}$, for Rumodified azurins. Solid line corresponds to an exponential decay constant $\beta=1.1 \AA^{-1}$. 


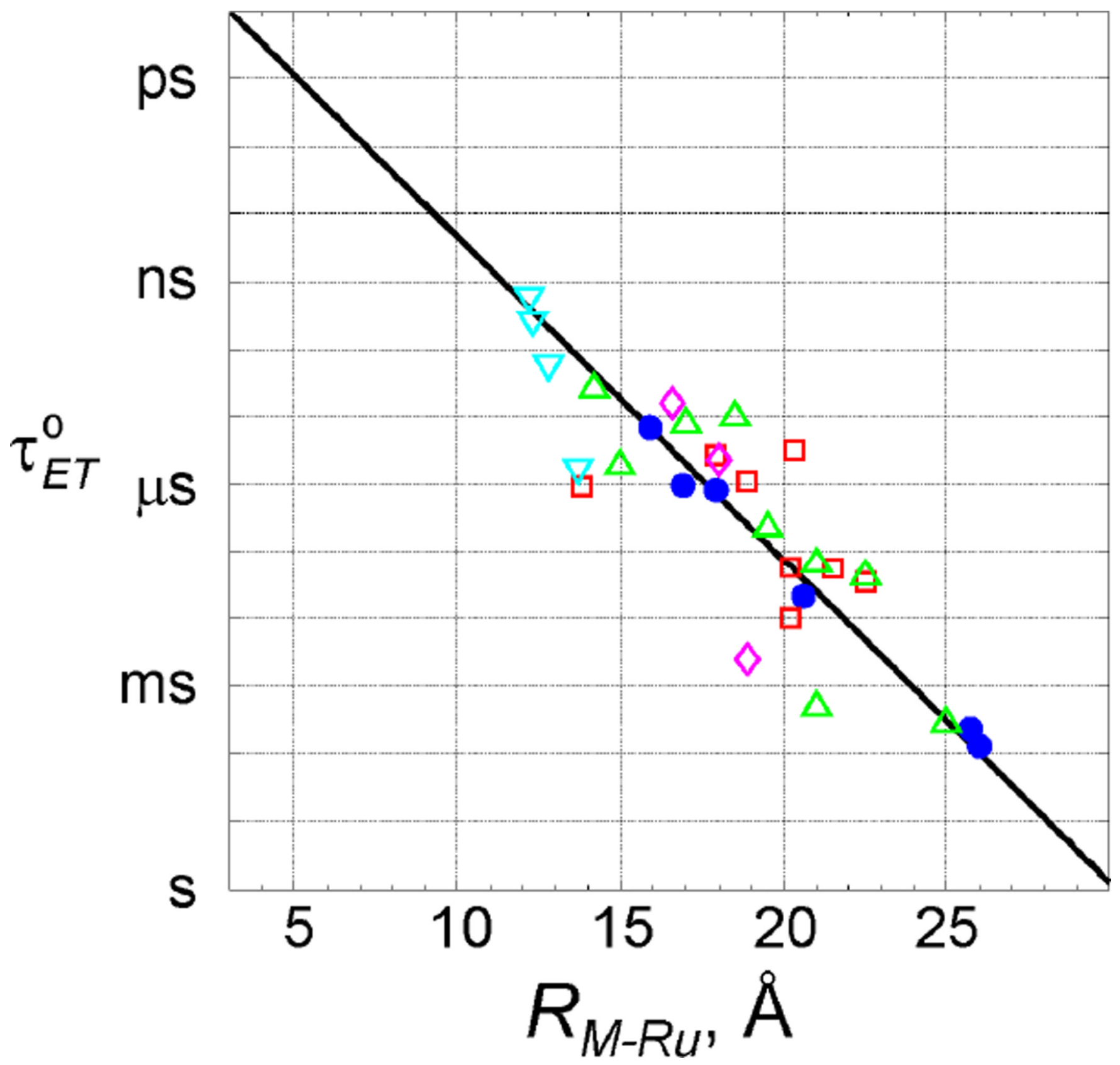

Figure 4.

Dependence of driving-force-optimized tunneling times, $\tau_{E T}^{\mathrm{o}}=\left(k_{E T}^{\mathrm{o}}\right)^{-1}$, on D-A distance in Ru-proteins: azurin $(\bigcirc)$; cytochrome $c(\square)$; myoglobin $(\diamond)$; cytochrome b562 $(\triangle)$; and $\operatorname{HiPIP}(\nabla)$. 


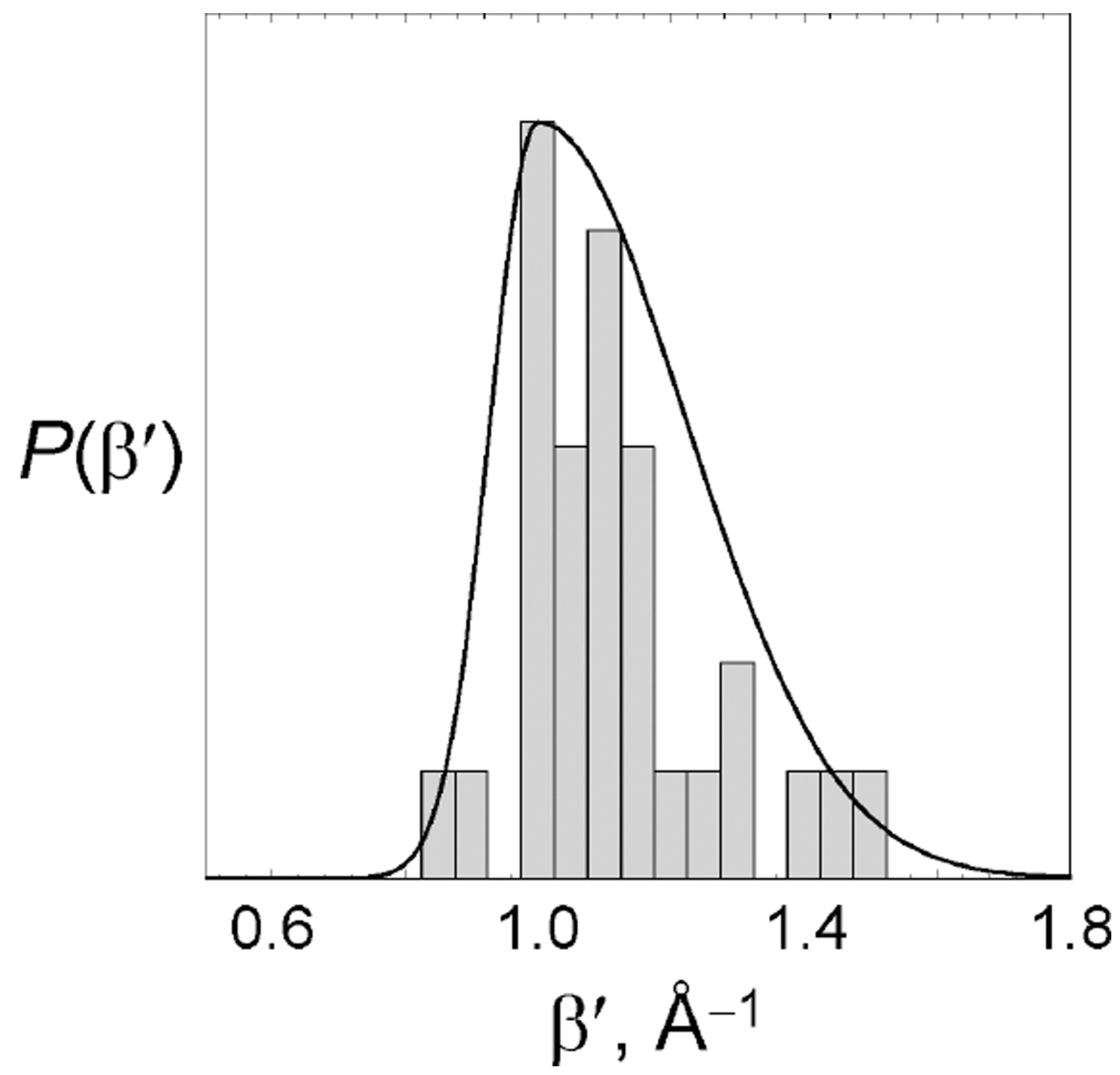

Figure 5.

Plot of the distribution of $\beta$ values extracted from ET kinetics in Ru-proteins. 


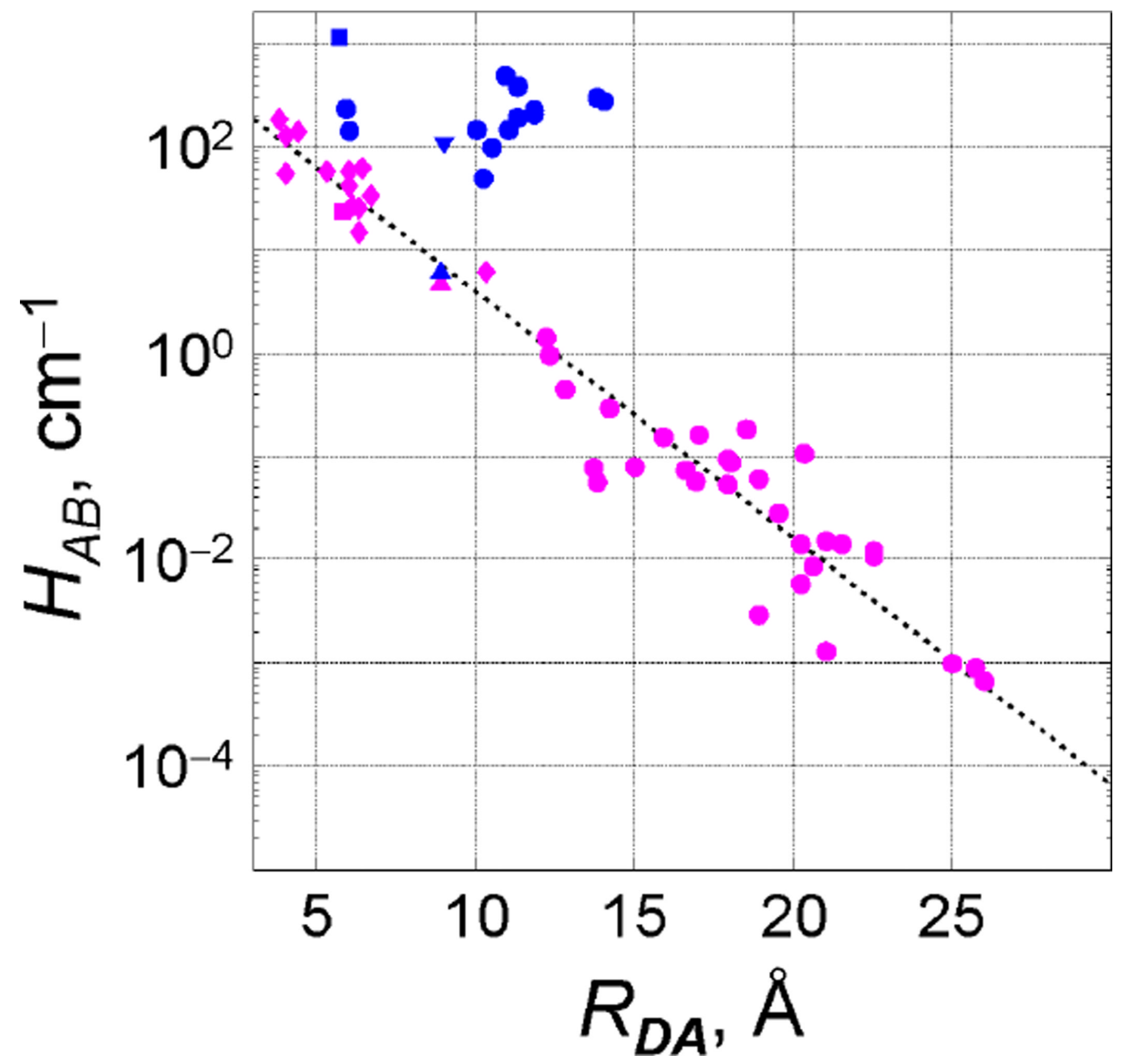

Figure 6.

Plot of $H_{A B}$ as a function of D-A distance for thermal (red, magenta) and optical (blue) intramolecular ET reactions. Data sources: (๑) Ru-modifed proteins; ${ }^{35}(\square) \mathrm{Ir}_{2} \leftrightarrow$ pyridinium ET (Fox et $\left.a l^{71}\right)$; $(\mathbf{\Delta}, \mathbf{\Delta})$ binuclear Fe polypyridyl complexes (Elliott et $a l^{72}$ ); ( $)$ biphenyl \left. anion to naphthalene ET (Closs $e{ } a l^{73}\right)$; ( $\left.\mathbf{\nabla}\right)$ dithiaspirane-bridged Ru-ammine complexes $\left(\right.$ Stein et $\left.\mathrm{l}^{75}\right)$; ( ) N-heterocycle-bridged Ru ammine complexes $\left(\mathrm{Creutz}^{76}\right)$; (ם) arylbridged bis-hydrazine compounds (Nelson et $a l^{77}$ ). 


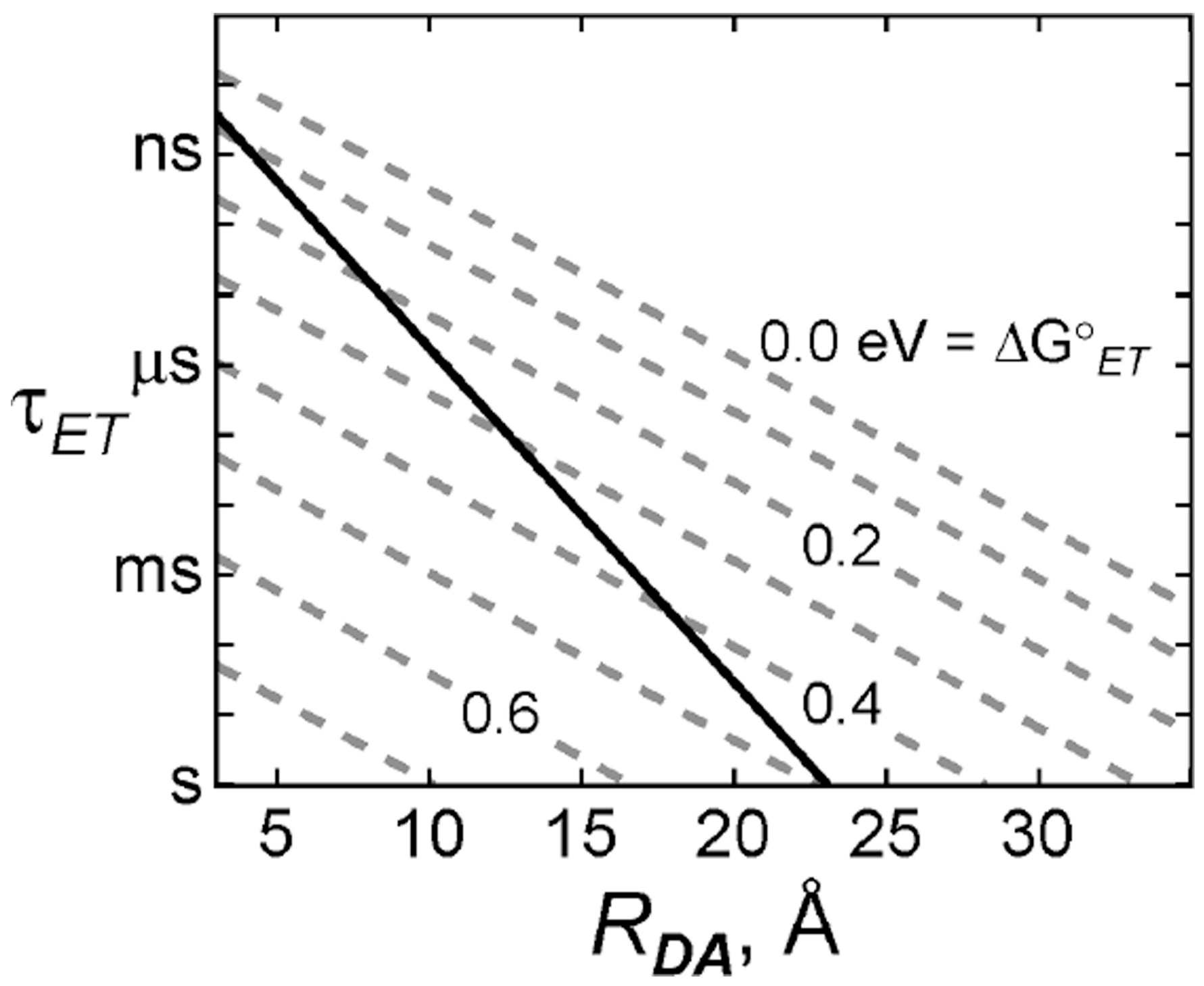

Figure 7.

Distance dependences of the rates of single-step and two-step electron tunneling reactions. Solid black line indicates the theoretical distance dependence for a single-step, ergoneutral $\left(\Delta \mathrm{G}_{\mathrm{RP}}^{\circ}=0\right)$ tunneling process $\left(\beta=1.1 \AA^{-1}\right)$. Dashed gray lines are distance dependences calculated for two-step ergoneutral tunneling ( $\mathrm{R} \leftrightarrow \mathrm{H} \leftrightarrow \mathrm{P}$ ) with the indicated standard freeenergy changes for the $\mathrm{R} \leftrightarrow \mathrm{H}$ step. 


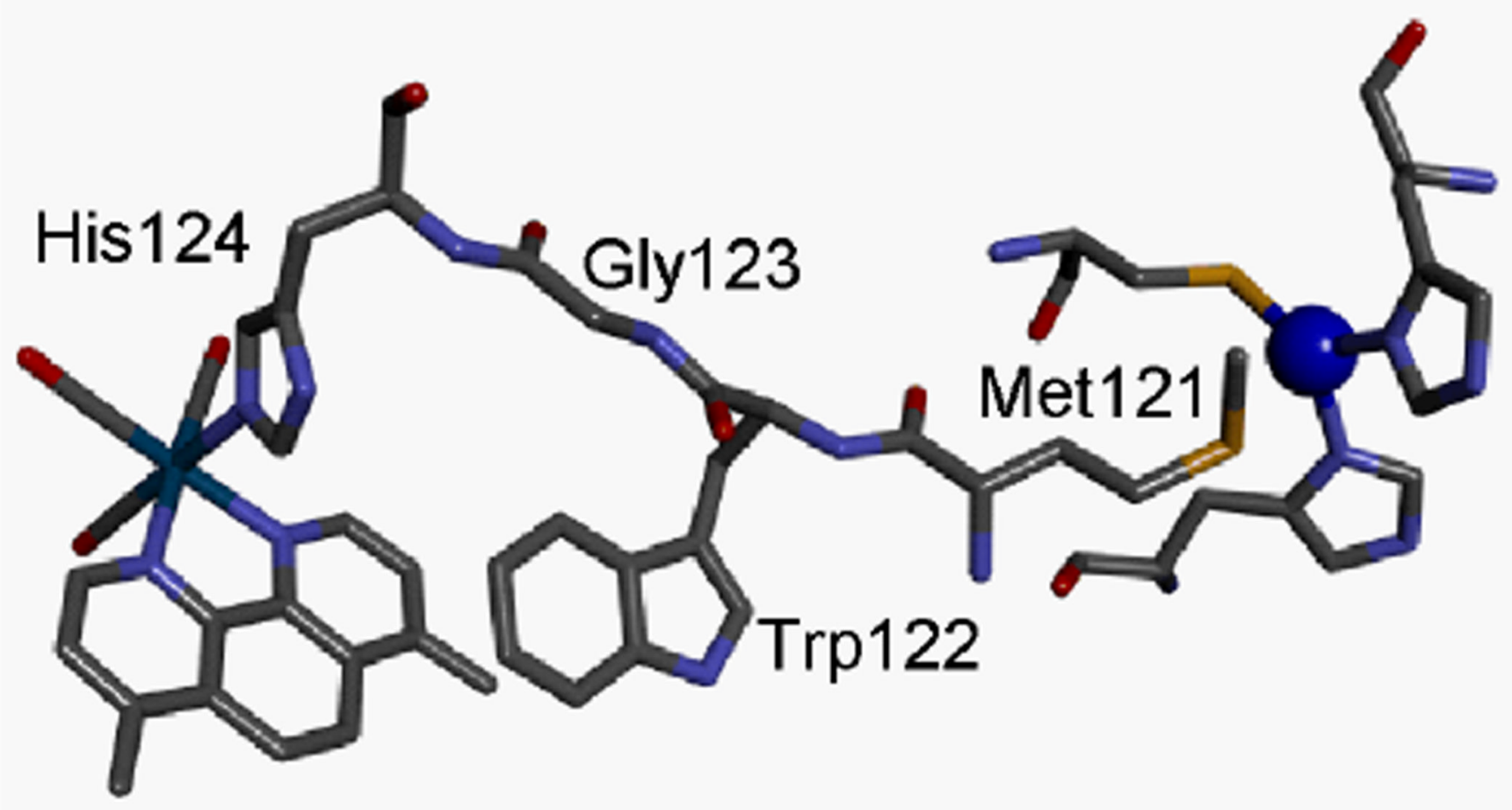

Figure 8.

Model of the polypeptide backbone between $\mathrm{Re}$ and $\mathrm{Cu}$ in $\mathrm{Re}(\mathrm{CO})_{3}(\mathrm{dmp})(\mathrm{His} 124)$ (Trp122)|Az (from PDB \#2I7O). 


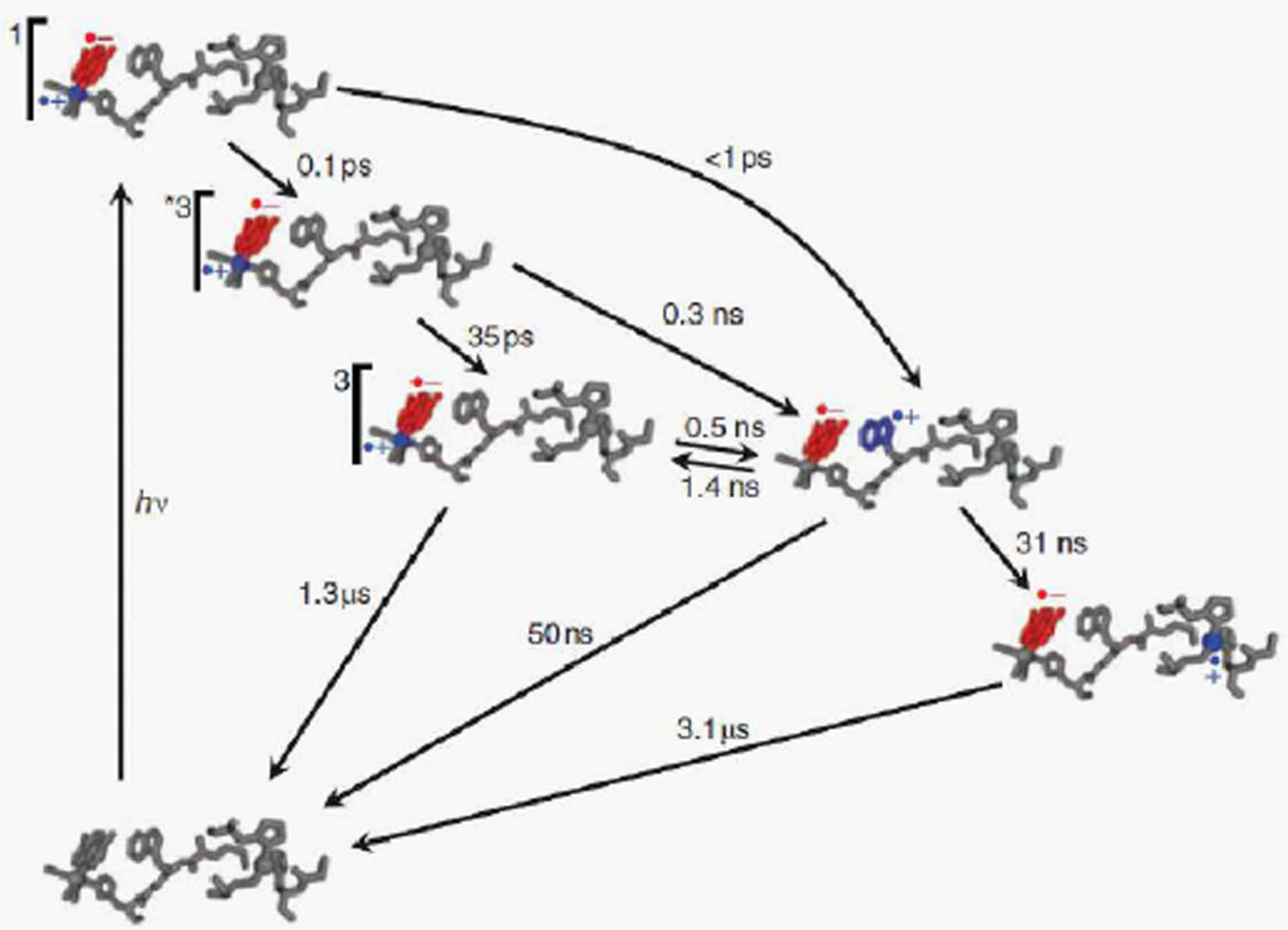

Figure 9.

Kinetics model of photoinduced electron transfer in $\operatorname{Re}(\mathrm{CO})_{3}(\mathrm{dmp})(\mathrm{His} 124)|(\operatorname{Trp} 122)| \mathrm{Az}$. Light absorption produces electron (red) and hole (blue) separation in the MLCT-excited $\mathrm{Re}^{\mathrm{I}}$ complex. Migration of the hole to $\mathrm{Cu}^{\mathrm{I}}$ via $(\mathrm{W} 122)^{\bullet+}$ is complete in less than $50 \mathrm{~ns}$. Charge recombination proceeds on the microsecond time scale. (Reproduced from ref 152 with permission from AAAS.) 


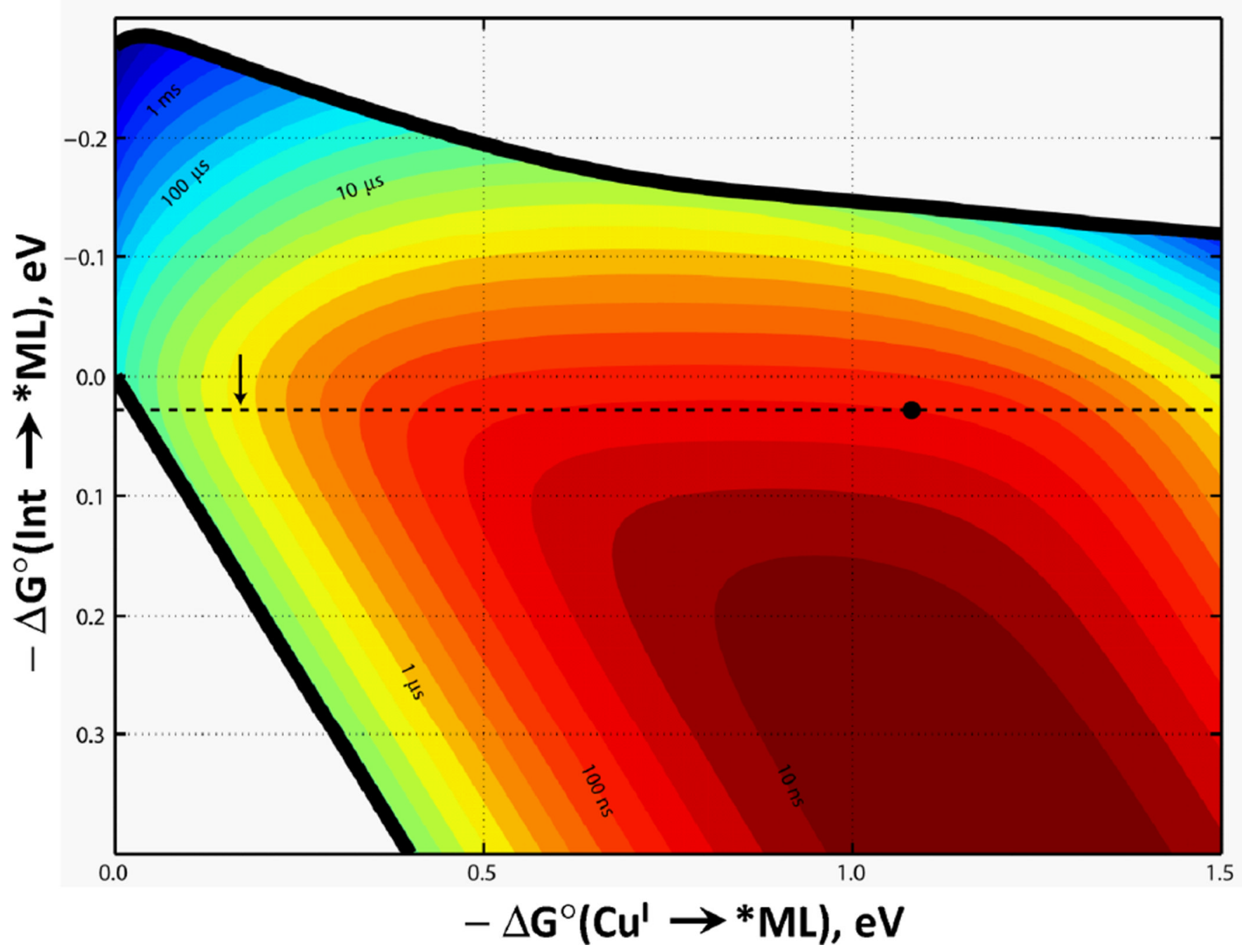

Figure 10.

Two-step hopping map for electron tunneling through $\mathrm{Re}^{\mathrm{I}}$-modified azurin. Colored contours reflect electron-transport time scales as functions of the driving force for the first tunneling step (ordinate, $\mathrm{Int} \rightarrow * \mathrm{ML}$ ) and the overall electron-transfer process (abscissa, $\mathrm{Cu}^{\mathrm{I}}$ $\rightarrow * \mathrm{ML})$. The heavy black lines enclose the region in which two-step hopping is faster than single-step tunneling. The dashed black line indicates the driving force for $* \mathrm{Re}^{\mathrm{II}}(\mathrm{CO})_{3}\left(\mathrm{dmp}^{\bullet-}\right)(\mathrm{His} 124)|(\operatorname{Trp} 122)| \mathrm{AzCu}^{\mathrm{I}} \rightarrow \mathrm{Re}^{\mathrm{I}}(\mathrm{CO})_{3}\left(\mathrm{dmp}^{\bullet-}\right)(\operatorname{His} 124)\left|(\operatorname{Trp} 122)^{\bullet+}\right|$ $\mathrm{AzCu}^{\mathrm{I}} \mathrm{ET}$; the black dot corresponds to $* \mathrm{Re}^{\mathrm{II}}(\mathrm{CO})_{3}\left(\mathrm{dmp}^{\circ-}\right)(\mathrm{His} 124)|(\operatorname{Trp} 122)| \mathrm{AzCu}{ }^{\mathrm{I}} \rightarrow$ $\operatorname{Re}^{\mathrm{I}}(\mathrm{CO})_{3}\left(\mathrm{dmp}^{\bullet-}\right)(\mathrm{His} 124)\left|(\operatorname{Trp} 122)^{\bullet+}\right| \mathrm{AzCu}^{\mathrm{I}} \rightarrow \mathrm{Re}^{\mathrm{I}}(\mathrm{CO})_{3}\left(\mathrm{dmp}^{\bullet-}\right)(\mathrm{His} 124)|(\operatorname{Trp} 122)| \mathrm{AzCu}^{\mathrm{II}}$ hopping. (Reproduced from ref 152 with permission from AAAS.) 

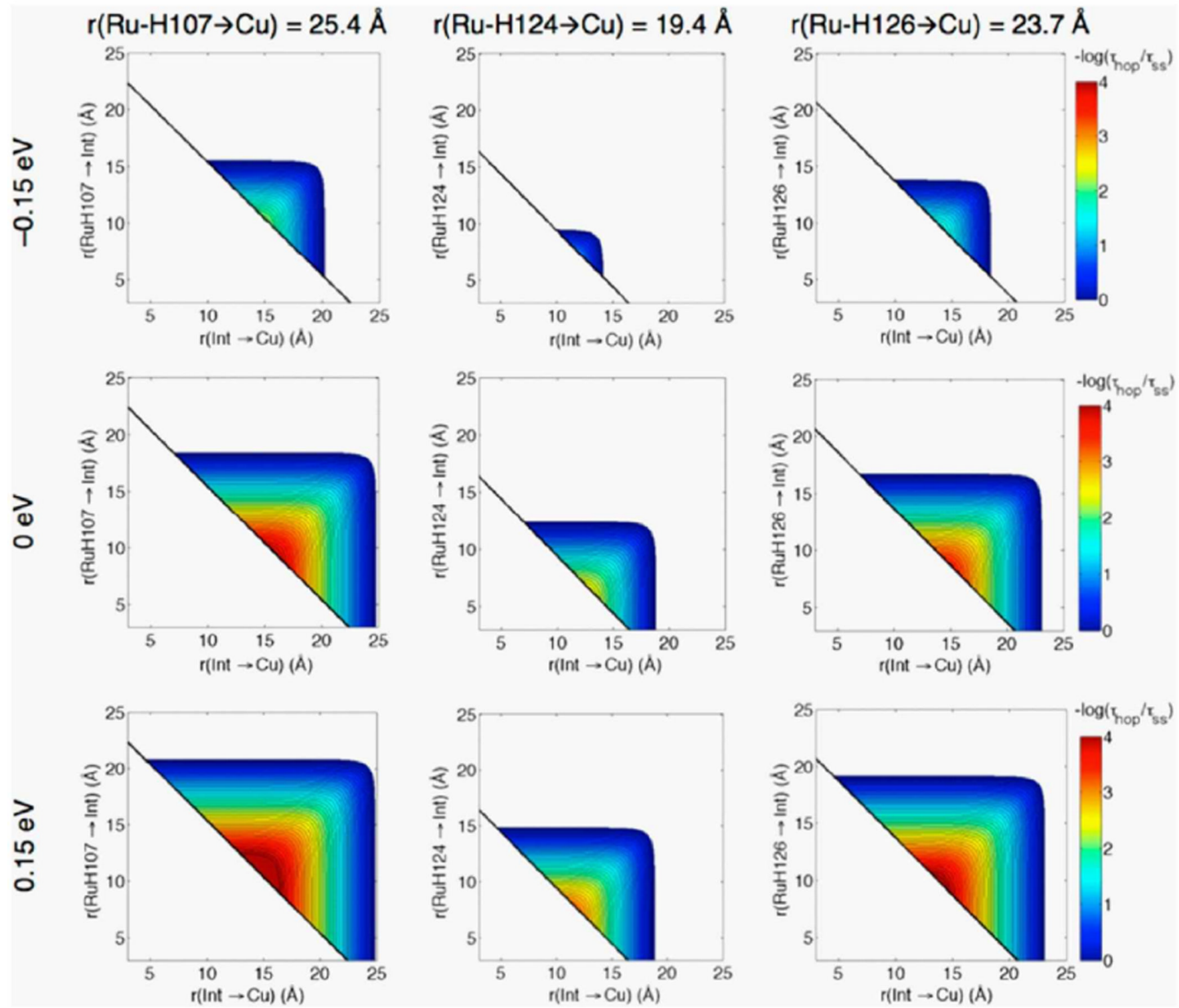

Figure 11.

Hopping advantage maps for a two-step ET system $\left(\mathrm{Cu}^{\mathrm{I}} \rightarrow \mathrm{Int} \rightarrow \mathrm{Ru}^{\mathrm{III}}\right)$ in each of three azurins. In each map the overall driving force $-\Delta \mathrm{G}^{\circ}\left(\mathrm{Cu}^{\mathrm{I}} \rightarrow \mathrm{Ru} \mathrm{III}^{\mathrm{III}}\right)$ is $0.7 \mathrm{eV}$, the reorganization energy $(\lambda)$ is $0.8 \mathrm{eV}, \mathrm{T}$ is $298 \mathrm{~K}$, the distance decay constant $(\beta)$ is $1.1 \AA^{-1}$, and the close-contact rate constant is $\left(k_{E T^{\circ}}\right)$ is $10^{13} \mathrm{~s}^{-1}$. $\tau_{h o p}$ is the calculated hopping rate constant and $\tau_{s s}$ is the calculated single-step rate constant. The first step driving forces ( $-\Delta \mathrm{G}$ $\left.{ }^{\circ}\left(\mathrm{Int} \rightarrow \mathrm{Ru}^{\mathrm{III}}\right)\right)$ are indicated at the left. The contour lines are plotted at $0.1 \log$ unit intervals. (Reprinted with permission from J. Am. Chem Soc2013135(30), 11151-11158. Copyright 2013 American Chemical Society.) 

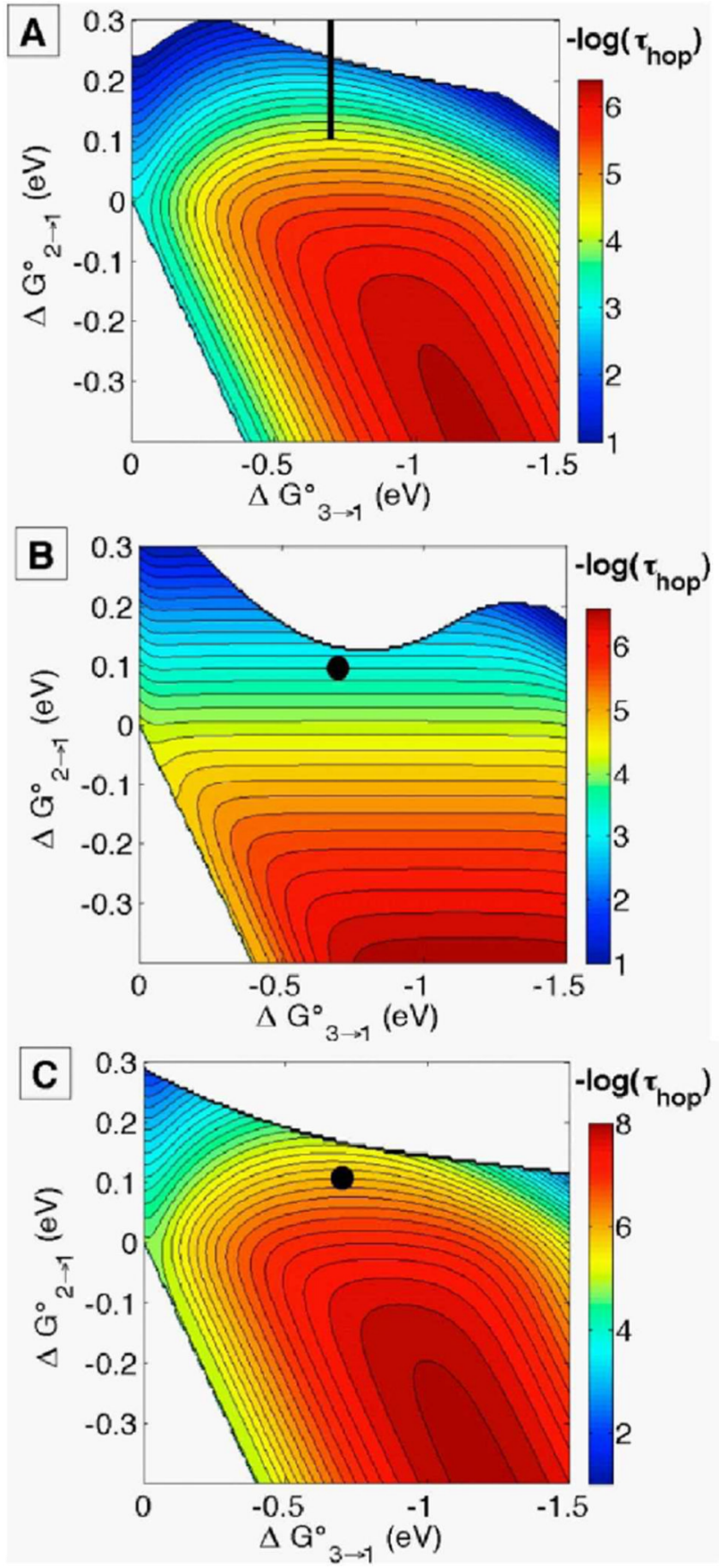

Figure 12.

Hopping maps for $\mathrm{NO}_{2} \mathrm{YO}^{-}$-substituted azurins: (A) RuH107NO $\mathrm{YO}^{-} 109$ with $\mathrm{r}_{1}=11.4, \mathrm{r}_{2}$ $=16.7, \mathrm{r}_{\mathrm{T}}=25.4 \AA$. (B) RuH126NO $\mathrm{NO}^{-} 122$ with $\mathrm{r}_{1}=14.2, \mathrm{r}_{2}=13.3, \mathrm{r}_{\mathrm{T}}=23.7 \AA$. (C) RuH124NO $\mathrm{YO}^{-122}$ with $\mathrm{r}_{1}=7.8, \mathrm{r}_{2}=13.3, \mathrm{r}_{\mathrm{T}}=19.4 \AA$. In all maps $\lambda=0.8 \mathrm{eV}, \beta=1.1$ $\AA^{-1}, \mathrm{~T}=298 \mathrm{~K}$, and $k_{E T}{ }^{\circ}=10^{13} \mathrm{~s}^{-1}$. The subscripts 1,2 , and 3 refer to $\mathrm{Ru}^{\mathrm{III}}, \mathrm{NO}_{2} \mathrm{YO}^{-}$, and $\mathrm{Cu}^{\mathrm{I}}$ respectively. The contour lines are plotted at $0.2 \log$ unit intervals. The black dots (or black bar in (A)) correspond the driving forces estimated for the Ru-proteins. (Reprinted with permission from J. Am. Chem Soc2013135(30), 11151-11158. Copyright 2013 American Chemical Society.) 


\section{Table 1}

Self-exchange reorganization energies for selected metal-aquo ions and metalloproteins.

\begin{tabular}{|c|c|c|}
\hline Redox Center & Protein & $\lambda, \mathrm{eV}$ \\
\hline$\left[\mathrm{Fe}\left(\mathrm{OH}_{2}\right)_{6}\right]^{3+/ 2+}$ & & $2.5(1)^{a}$ \\
\hline$\left[\mathrm{Co}\left(\mathrm{OH}_{2}\right)_{6}\right]^{3+/ 2+}$ & & $3.7(1)^{a}$ \\
\hline$\left[\mathrm{Ru}\left(\mathrm{OH}_{2}\right)_{6}\right]^{3+/ 2+}$ & & $1.8(1)^{a}$ \\
\hline$\left[\mathrm{Fe}(\mathrm{heme})\left(\mathrm{S}_{\mathrm{Met}}\right)\left(\mathrm{N}_{\mathrm{His}}\right)\right]$ & cytochrome $^{c}$ & $0.7(1)^{b}$ \\
\hline$\left[\mathrm{Cu}\left(\mathrm{S}_{\mathrm{Cys}}\right)\left(\mathrm{N}_{\mathrm{His}}\right)_{2}\right]$ & azurin & $0.7(1)^{c}$ \\
\hline$\left[\mathrm{Cu}_{2}\left(\mu-\mathrm{S}_{\mathrm{Cys}}\right)_{2}\left(\mathrm{~N}_{\mathrm{His}}\right)_{2}\right]$ & $\mathrm{Cu}_{\mathrm{A}}$ domain & $<0.5(1)^{d}$ \\
\hline$\left[\mathrm{Fe}_{4} \mathrm{~S}_{4}\left(\mathrm{~S}_{\mathrm{Cys}}\right)_{4}\right]$ & $\mathrm{HiPIP}^{e}$ & $0.6(2)^{f}$ \\
\hline \multicolumn{3}{|l|}{ N. Sutin 38} \\
\hline \multicolumn{3}{|l|}{${ }^{b}$ Mines et $a l^{43}$} \\
\hline \multicolumn{3}{|l|}{${ }^{c}$ DiBilio et al ${ }^{44}$} \\
\hline \multicolumn{3}{|c|}{$d_{\text {P. Brzezinski; }}{ }^{45}$ O. Farver et al. $;{ }^{46}$ B. E. Ramirez et a } \\
\hline \multicolumn{3}{|c|}{${ }^{e}$ High potential iron protein. } \\
\hline$f_{\text {E. Babini } \text { et } a l^{48}}$ & & \\
\hline
\end{tabular}

